\title{
CHARACTERIZATION OF A HIGHLY NEUTRALIZING SINGLE MONOCLONAL ANTIBODY TO BOTULINUM NEUROTOXIN TYPE
}

A

Sébastien Brier ${ }^{1}$, Christine Rasetti-Escargueil ${ }^{2}$, Anne Wijkhuisen ${ }^{3}$, Stéphanie Simon $^{3}$, Maud Marechal $^{2}$, Emmanuel Lemichez ${ }^{2}$, Michel R. Popoff ${ }^{*}$

${ }^{1}$ Biological NMR Technological Plateform, Institut Pasteur, CNRS UMR3528, 75015 Paris, France

${ }^{2}$ Institut Pasteur, Toxines Bactériennes, CNRS ERL6002, 75015 Paris, France

${ }^{3}$ Université Paris-Saclay, CEA, INRAE, Département Médicaments et Technologies pour la santé, 91191 Gif-sur-Yvette, France

\section{- Corresponding author popoff2m@gmail.com, Ph 33643551035}

\section{ABSTRACT (228 mots)}

Compared to conventional antisera strategies, monoclonal antibodies (mAbs) represent an alternative and safer way to treat botulism, a fatal flaccid paralysis due to botulinum neurotoxins (BoNTs). In addition, mAbs offer the advantage to be produced in a reproducible manner. We previously identified a unique and potent mouse mAb (TA12) targeting BoNT/A1 with high affinity and neutralizing activity. In this study, we characterized the molecular basis of TA12 neutralization by combining Hydrogen/Deuterium eXchange Mass Spectrometry (HDX-MS) with site directed mutagenesis and functional studies. We found that TA12 recognizes a conformational epitope located at the interface between the $\mathrm{H}_{\mathrm{CN}}$ and $\mathrm{H}_{\mathrm{CC}}$ subdomains of the BoNT/A1 receptor-binding domain $\left(\mathrm{H}_{\mathrm{C}}\right)$. The TA12 binding interface shares common structural features with the ciA-C2 VHH epitope and lies on the face opposite recognized by ciA-C2 and the CR1/CR2 neutralizing mAbs. The single substitution of N1006 was sufficient to affect TA12 binding to $\mathrm{H}_{\mathrm{C}}$ confirming the position of the epitope. We further uncovered that the TA12 epitope overlaps with the BoNT/A1 binding site for both the neuronal cell surface receptor synaptic vesicle glycoprotein 2 isoform C (SV2C) and the GT1b ganglioside. Hence, TA12 potently blocks the entry of BoNT/A1 into neurons by interfering simultaneously with the binding of SV2C and to a lower extent GT1b. Our study reveals the unique neutralisation 
33 mechanism of TA12 and emphasizes on the potential of using single mAbs for the treatment of 34 botulism type A.

35

36 Key Words

37 Botulinum neurotoxin; Botulism; Monoclonal antibody; Synaptic vesicle protein 2; GT1b,

38 Mass spectrometry; Hydrogen-Deuterium eXchange; Epitope mapping

39

40 Running title

41 Potent neutralization of BoNT/A1 with a single mAb

42

43 Nonstandard abbreviations

44 BoNT, botulinum neurotoxin

45 L, light chain

$46 \mathrm{H}$, heavy chain

$47 \quad \mathrm{H}_{\mathrm{C}}$, half $\mathrm{C}$-terminal $\mathrm{H}$ chain

$48 \mathrm{H}_{\mathrm{N}}$, half $\mathrm{N}$-terminal $\mathrm{H}$ chain

49 SV2C, synaptic vesicle protein $2 \mathrm{C}$

50 gSV2C, glycosylated SV2C

51 SNARE, soluble $N$-ethylmaleimide-sensitive-factor attachment protein receptor

$52 \mathrm{mAb}$, monoclonal antibody

53 HDX-MS, Hydrogen/Deuterium eXchange Mass Spectrometry

54 TCEP, Tris(2-carboxylethyl)phosphine

55 EIA, enzyme immunoassay

56 LD, luminal domain

57 BSA, bovine serum albumin

58 AMC, anit-mouse Fc

59 TGY, trypticase-glucose-yeat extract

60 VHH, variable domain of heavy chain

61 MLD, mouse lethal dose

62 


\section{INTRODUCTION}

Botulism is a rare but severe disease that results from botulinum neurotoxin (BoNT) intoxication. Naturally acquired botulism can develop in three main forms: foodborne BoNT intoxication, intestinal colonization by BoNT-producing clostridium (infant botulism and more rarely botulism by intestinal colonization in adults), or wound botulism. Among the seven different BoNT toxinotypes, BoNT/A is the most potent toxin with a lethal dose for human estimated at $\sim 1 \mathrm{ng} / \mathrm{kg}$ by parenteral route $(1,2)$. BoNTs and specially the BoNT/A toxinotype are therefore classified by the Centers for Diseases Control and Prevention (CDC) among the six major bioterrorism agents (category A) (3). BoNT/A is a $~ 1296$ residues long protein that is proteolytically processed into a light $(\mathrm{L})$ and a heavy chain $(\mathrm{H})$ linked by a single disulfide bond. The L chain contains the intracellularly active enzymatic site that specifically cleaves neuronal members of the $\mathrm{N}$-ethylmaleimide sensitive factor attachment protein receptors (SNAREs) complex required for the release of acetylcholine. The C-terminal $\mathrm{H}$ chain $\left(\mathrm{H}_{\mathrm{C}}\right)$ recognizes both the intraluminal loop of the synaptic vesicle glycoprotein $2 \mathrm{C}$ (SV2C) and GT1b/GD1 a gangliosides as functional dual receptors on neuronal cells. Finally, the N-terminal $\mathrm{H}$ domain $\left(\mathrm{H}_{\mathrm{N}}\right)$ is involved in the translocation of the $\mathrm{L}$ chain from endocytic vesicles into the cytosol of neuronal cell targets (4-11).

Antitoxin serotherapies are currently the only specific and available treatments for botulism. The clinical benefit and effectiveness of such therapies remain however linked to their use at the early onset of the disease only. The equine antitoxin therapy composed of polyclonal IgG antibodies is the most available treatment although it is often associated to hypersensitivity reactions including serum sickness and cardiac arrest $(12,13)$. Human botulism-immune globulins from vaccinated donors have been developed notably for the treatment of infant botulism (14). The first one-BabyBIG, is supplied by the California Department of Public Health, but with limited stock. This formulation has been recently discontinued and will be replaced with a new formulation currently under clinical development (15). Recently, the safety of a new cocktail composed of three humanized mAbs (XOMA 3B) engineered to neutralize BoNT/A subclasses has been evaluated and confirmed in healthy volunteers (16). The European AntiBotABE Program has allowed the isolation of recombinant humanized antibodies neutralizing BoNT/A, B and E. Protective antibody combinations against BoNT/A and BoNT/B showed cross-neutralization of both BoNT/A1 and A2 as well as BoNT/B1 and B2, repectively (17).

Monoclonal antibodies (mAbs) represent therefore a promising alternative strategy to treat botulism with the advantage of being better tolerated by patients and produced in a more 
reproducible and safer way than animal hyperimmune serum. Various murine or humanized mAbs raised against whole BoNTs or BoNT subdomains have been evaluated for their neutralizing potency and their possible therapeutic use (review in $(17,18)$ ). Most often, efficient toxin neutralization requires a combination of several mAbs. For example, the association of three mAbs has been reported to neutralize BoNT/A, BoNT/E, or BoNT/F, respectively (1921). Recently, a single anti-BoNT/A tri-epitopic $\mathrm{mAb}$ with equivalent binding and neutralization potency than three distinct mAbs has been generated (22). The use of a single $\mathrm{mAb}$ as alternative therapeutic antitoxin agent appears therefore promising and offers the advantage to simplify the process of development and to reduce the cost of production.

We previously reported a potent neutralizing murine $\mathrm{mAb}$ (named TA12) generated against the C-terminal domain of the BoNT/A1 heavy chain $\left(\mathrm{H}_{\mathrm{C}} \mathrm{A} 1\right)(23,24)$. In this study, we focused on the structural characterization of the TA12: $\mathrm{H}_{\mathrm{C}} \mathrm{A} 1$ complex by Hydrogen/Deuterium eXchange Mass Spectrometry (HDX-MS) approach combined with site directed mutagenesis and functional assays $(25,26)$. We report that TA12 targets a conformational epitope on $\mathrm{H}_{\mathrm{C}} \mathrm{A} 1$ located at the junction between the $\mathrm{H}_{\mathrm{CC}}$ and the $\mathrm{H}_{\mathrm{CN}}$ subdomains. The TA12 epitope overlaps with both the SV2C cell receptor and the GT1b binding sites, hence perturbing the dual-receptor binding process required for the entry of BoNT/A1 into neuronal cells.

\section{MATERIALS AND METHODS}

\section{Biological reagents}

mAb TA12 was prepared and affinity purified on protein A beads (Prosep-A High capacity, Millipore, Billerica, USA) as previously described (27).

Recombinant $\mathrm{H}_{\mathrm{C}}$ of BoNT/A1 ( $\left.\mathrm{H}_{\mathrm{C}} \mathrm{A} 1\right)$, corresponding to the receptor binding domain of BoNT/A1 was prepared as previously described (28). DNAs encoding $\mathrm{H}_{\mathrm{C}}$ of BoNT/A subtypes were PCR amplified with primers and $C$. botulinum genomic DNA (Extended Table 1) and cloned into pET28a. Recombinant $\mathrm{H}_{\mathrm{C}}$ containing N-terminal 6xHis-tag were produced and purified as previously described (28). Primers used to generate $\mathrm{H}_{\mathrm{C}} \mathrm{A} 1$ mutants are indicated in

\section{Extended Table 2.}

cDNA encoding the human intraluminal SV2C fragment L4 (amino acid 454 to 579, hereafter named SV2C-LD) was PCR amplified as previously described (29). Briefly, DNA encoding the amino acids 454 to 579 of human SV2C was PCR amplified with primers P1415 (5'- GGATCCTTCCCTGATGTCATTAAACCTCTG-3') and P1416 (5'GAATTCCTAGTAGGCACTATAGTCATCATCAAA-3') adding BamHI and EcoRI restriction sites, respectively, and was cloned into pGEX-2T at the corresponding restriction 
131 sites. The construction was verified by DNA sequencing. The fusion protein (41 kDa) contains

132 N-terminal GST and C-terminal SV2C-LD linked by Gly-Ser resulting from the BamHI site.

133 The recombinant plasmid was cloned into E. coli BL21 DE3 and the resulting bacterial strain 134 was grown in LB medium containing ampicillin $(100 \mu \mathrm{g} / \mathrm{ml})$. The culture was induced with 135 IPTG $(0.2 \mathrm{mM})$ and further grown at $18^{\circ} \mathrm{C}$ for $18 \mathrm{~h}$. The bacterial cells were washed with 136 distilled water, suspended in $50 \mathrm{mM}$ Tris, $150 \mathrm{mM} \mathrm{NaCl}, 10 \mathrm{mM} \mathrm{MgCl} 2,1 \mathrm{mM}$ dithiotreitol, $1370.1 \%$ Tween20 containing complete protease inhibitor cocktail EDTA free (Roche, France), 138 and lyzed by ultrasonication. The lysate was incubated with Glutathione-Sepharose-4B beads 139 (GE Healthcare) for $1 \mathrm{~h}$ at $4^{\circ} \mathrm{C}$. The beads were washed three times with the same buffer and a $50 \%$ suspension in the same buffer was used for the pull-down assays.

For HDX-MS experiments, 6His-tag-SV2C-LD was used. The PCR amplified DNA

142 encoding SV2C-LD was cloned into pET28 vector at the BamHI-EcoRI site. The recombinant N-terminal 6His-tag-SV2C-LD protein was produced in E. coli BL21 DE3 and purified on a Talon metal affinity matrix (Clontech) equilibrated in $10 \mathrm{mM}$ Tris, $150 \mathrm{mM} \mathrm{NaCl}, 10 \mathrm{mM}$ imidazole, $10 \mathrm{mM}$ TCEP, $\mathrm{pH}$ 7.5. The recombinant protein was eluted with the same buffer supplemented with $100 \mathrm{mM}$ imidazole and dialyzed against the same buffer without imidazole.

\section{Affinity determination of mAb TA12}

The affinities of mAb TA12 for different recombinant $\mathrm{H}_{\mathrm{C}} \mathrm{BoNT}$ isoforms were determined by Bio-layer Interferometry using the ForteBio system (Pall Laboratory). mAb TA12 prepared at $10 \mu \mathrm{g} / \mathrm{mL}$ in EIA (enzyme immunoassay) buffer (0.1 M phosphate buffer, $\mathrm{pH} 7.4,0.15 \mathrm{M}$ $\mathrm{NaCl}, 0.1 \% \mathrm{BSA}$, and $0.01 \%$ sodium azide) + 0.02\% Tween 20 (Sigma) was dispensed in 96well microplates at a volume of $200 \mu \mathrm{L}$ per well. The same concentration occupied 8 vertical wells. In other wells, recombinant $\mathrm{H}_{\mathrm{C}} \mathrm{BoNT}$ proteins were dispensed at 8 titrated concentrations (between 100 and $0 \mathrm{nM}$ depending on the protein). A glycine (Sigma, $\mathrm{pH}$ [1.4]) regeneration solution and EIA buffer $+0.02 \%$ Tween 20 for baseline stabilization and neutralization was also prepared. The plate was agitated at $1000 \mathrm{rpm}$ over the entire course of the experiment. Prior to the binding measurements, the anti-mouse Fc (AMC) sensors tips were hydrated in EIA buffer $+0.02 \%$ tween 20 . The sensor tips were then transferred to the EIA buffer $+0.02 \%$ Tween 20 for the baseline, then for $300 \mathrm{sec}$ into wells containing mAb for loading step. After baseline step in EIA buffer $+0.02 \%$ Tween 20 for $60 \mathrm{sec}$, the binding kinetics were measured by dipping the mAb-coated sensors into the wells containing recombinant $\mathrm{H}_{\mathrm{C}} \mathrm{BoNT}$ at varying concentrations. The binding interactions were monitoring over a $900 \mathrm{sec}$ associated period and followed by a $900 \mathrm{sec}$ dissociation period in the wells containing EIA buffer $+0.02 \%$ Tween 
165

166

167

168

169

170

171

172

173

174

175

176

177

178

179

180

181

182

183

184

185

186

187

188

189

190

191

192

193

194

195

196

197

20. Between each binding cycle, the AMC sensors tips were regenerated with wells containing glycine and neutralized in the EIA buffer $+0.02 \%$ tween 20 . The equilibrium dissociation constant $\left(\mathrm{K}_{\mathrm{D}}\right)$ was calculated using the ratio between the dissociation rate constant $\left(\mathrm{k}_{\mathrm{off}}\right)$ and the association rate constant $\left(\mathrm{k}_{\mathrm{on}}\right)$, obtained with a global Langmuir 1:1 fit (Octet Data Analysis software, vHT.10).

\section{GST pull down assay}

Recombinant SV2C-LD immobilized on glutathione-Sepharose-4B matrix (GE healthcare, France) ( $30 \mu \mathrm{L}$ of $50 \%$ bead suspension) was incubated for 90 min at $4{ }^{\circ} \mathrm{C}$ with $\mathrm{H}_{\mathrm{C}} \mathrm{A} 1$ solutions prepared with or without mAb TA12 in $50 \mathrm{mM}$ Tris buffer, $150 \mathrm{mM} \mathrm{NaCl}, 10 \mathrm{mM} \mathrm{MgCl} 2,2$ $\mathrm{mM}$ dithiothreitol, $0.1 \%$ Tween 20, $\mathrm{pH} 7.5$, supplemented with antiproteases (protease inhibitor cocktail EDTA free, Roche Diagnostics, Germany) (final volume $400 \mu \mathrm{L}$ ). $\mathrm{H}_{\mathrm{CA}} \mathrm{A}$ :TA12 solutions were pre-incubated for $15 \mathrm{~min}$ at room temperature before use. Beads were collected by centrifugation and washed three times with the same buffer. Washed pellets were suspended in SDS/2-mercaptoethanol sample buffer for $2 \mathrm{~min}$ at $95^{\circ} \mathrm{C}$ and analyzed by SDS-PAGE. Proteins were stained by Coomassie blue.

\section{Ganglioside binding assay}

Binding of $\mathrm{H}_{\mathrm{C}} \mathrm{Al}$ to the GT1b ganglioside was assessed in a solid phase assay as previously described (30-32). Briefly, bovine brain GT1b (Calbiochem, France) stored in dimethyl sulfoxide $(20 \mathrm{mg} / \mathrm{mL})$ at $-20^{\circ} \mathrm{C}$ was diluted in methanol and applied overnight to 96 well plates (Corning-Costar, France) at $2 \mu \mathrm{g}$ per well. Methanol was evaporated at room temperature and the plates were washed three times with phosphate-buffered saline containing $0.05 \%$ Tween 20 (Sigma, France) (PBST). Plates were blocked with 5\% non-fat skim milk in PBST for $1 \mathrm{~h}$ at room temperature and washed with PBST. $\mathrm{H}_{\mathrm{C}} \mathrm{A} 1$ was then dispensed (10 $\mathrm{nM} /$ well in PBS) in the control wells and incubated for $2 \mathrm{~h}$ at $4^{\circ} \mathrm{C}$. For competition with $\mathrm{mAb}$ TA12, $\mathrm{H}_{\mathrm{C}} \mathrm{A} 1(10 \mathrm{nM})$ was incubated with various concentrations of TA12 in $100 \mu \mathrm{L}$ PBS for $15 \mathrm{~min}$ at room temperature prior being applied to GT1b coated wells for $2 \mathrm{~h}$ at $4^{\circ} \mathrm{C}$. After washing with PBST, bound $\mathrm{H}_{C} \mathrm{~A} 1$ was detected with rabbit anti-H $\mathrm{H}$ A1 $(1: 10,000)(29)$ and horse radish peroxidase (HRP) goat anti-rabbit immunoglobulin $\operatorname{IgG}(1: 3,000)$ (Invitrogen, France). Ortho phenylendiamine (Sigma, France) was used as substrate $(1 \mathrm{mg} / \mathrm{mL}$ in citrate buffer $\mathrm{pH}$ 4.5 containing $\left.\mathrm{H}_{2} \mathrm{O}_{2}\right)$, and the reaction was stopped with $\mathrm{HCl} 3 \mathrm{M}(50 \mu \mathrm{L} /$ well). The extinction was measured at $490 \mathrm{~nm}$ and $650 \mathrm{~nm}$ as reference. 
199

200

201

202

203

204

205

206

207

208

209

210

211

212

213

214

215

216

217

218

219

220

221

222

223

224

225

226

227

228

229

\section{Neutralizing activity}

BoNTs were prepared from C. botulinum cultures in TGY (trypticase-glucose-yeast extract) medium for four days under anaerobic conditions at $37^{\circ} \mathrm{C}$ as previously described (33). Briefly, the cultures were acidified at $\mathrm{pH} 3.5$ with sulfuric acid, centrifuged at 10,000 x $\mathrm{g}$ for 15 min at $4^{\circ} \mathrm{C}$, washed with distilled water, and the BoNT complexes were extracted three times with $0.2 \mathrm{M}$ phosphate buffer $\mathrm{pH} 6.3$. BoNT complexes were precipitated with $65 \%$ ammonium sulfate saturation and then dialyzed against $50 \mathrm{mM}$ phosphate buffer, $\mathrm{pH} 6.3$ containing $0.2 \%$ gelatin (PB-G).

Mouse protection assay was performed with male Swiss mice (Charles River) weighing 20-22 g as previously described (34). Variable amounts of TA12 were incubated with 5 estimated mouse $50 \%$ lethal doses of either BoNT/A1, A2, A3, A5 or A7 in PB-G for 30 min at room temperature. The mixtures $(0.5 \mathrm{~mL})$ were then injected intraperitoneally into mice with control mice receiving BoNT alone. Mice were observed and any death was recorded every day during 4 days.

\section{Ethic statements}

All experiments were performed in accordance with French and European Community guidelines for laboratory animal handling. The protocols of experiments were approved by Institut Pasteur CETEA (Comité d'Ethique en Expérimentation Animale) with the agreement of laboratory animal use ( $\mathrm{N}^{\circ}$ 2013-0116) and by the Ministère de l'Education Nationale et de l'Enseignement Supérieur with the agreement 02026.02.

\section{HDX-MS experiments}

A summary of the HDX data containing the main experimental details is provided in Extended Table 3 (35). Prior to initiating the labeling, the quality of each protein was assessed by SDS-PAGE and intact mass analysis (Extended Figure 1).

Sample preparation. For epitope mapping, $\mathrm{H}_{\mathrm{C}} \mathrm{A} 1$ was labeled in both the presence and absence of the mouse mAb TA12. The TA12: $\mathrm{H}_{\mathrm{C}} \mathrm{A} 1$ complex was formed by mixing $3 \mu \mathrm{L}$ of $\mathrm{H}_{\mathrm{C}} \mathrm{A} 1$ (29 $\mu \mathrm{M}$ in buffer A: $10 \mathrm{mM}$ Tris, $150 \mathrm{mM} \mathrm{NaCl}, \mathrm{pH}$ 7.4) with $4.5 \mu \mathrm{L}$ of mAb TA12 (27 $\mu \mathrm{M}$ in buffer A). Control samples (unbound $\mathrm{H}_{\mathrm{C}} \mathrm{A} 1$ ) were prepared in parallel by replacing TA12 with buffer A. After $1 \mathrm{~h}$ incubation at $20^{\circ} \mathrm{C}$, the labeling was initiated by adding $67.5 \mu \mathrm{L}$ of 
231 deuterated buffer (10 mM Tris, $150 \mathrm{mM} \mathrm{NaCl}, \mathrm{pD}$ 7.4; $\mathrm{D}_{2} \mathrm{O} / \mathrm{H}_{2} \mathrm{O}$ ratio: 90/10\%). Assuming a

$232 \mathrm{~K}_{\mathrm{D}}$ value of $\sim 20 \mathrm{pM}(24)$ (and this study), $\sim 100 \%$ of $\mathrm{H}_{\mathrm{C}} \mathrm{A} 1$ remains bound to TA12 during 233 hydrogen exchange. Continuous labeling was performed at $20^{\circ} \mathrm{C}$ for $\mathrm{t}=0.16,1,5,10,30,60$ 234 and $120 \mathrm{~min}$. Aliquots of $10 \mu \mathrm{L}$ (i.e., 11.6 pmoles of $\mathrm{H}_{\mathrm{C}} \mathrm{A} 1$ ) were removed and quenched upon 235 mixing with $50 \mu \mathrm{L}$ of an ice cold solution of $2 \%$ formic acid, $4 \mathrm{M}$ urea to decrease the $\mathrm{pH}$ to 2.5 236 (Final $\mathrm{D}_{2} \mathrm{O} / \mathrm{H}_{2} \mathrm{O}$ ratio: 15/85\%). Quenched samples were immediately snap frozen in liquid nitrogen and stored at $-80^{\circ} \mathrm{C}$ until MS acquisition (less than 3 days).

An identical procedure was used to map the SV2C-LD interaction site on $\mathrm{H}_{\mathrm{C}} \mathrm{A} 1$. The SV2C-LD: $\mathrm{H}_{\mathrm{C}} \mathrm{A} 1$ complex was formed by mixing $3 \mu \mathrm{L}$ of $\mathrm{H}_{\mathrm{C}} \mathrm{A} 1(29 \mu \mathrm{M}$ in buffer A) with 4.5 $\mu \mathrm{L}$ of SV2C-LD (22 $\mu \mathrm{M}$ in buffer A supplemented with $10 \mathrm{mM}$ TCEP). The labeling was performed in the presence of $1 \mathrm{mM}$ TCEP at $20^{\circ} \mathrm{C}$. Assuming a $\mathrm{K}_{\mathrm{D}}$ value of $28 \mathrm{nM}(6), 90.5 \%$ of $\mathrm{H}_{\mathrm{C}} \mathrm{A} 1$ remains bound to SV2C-LD during labeling.

Undeuterated $\mathrm{H}_{\mathrm{C}} \mathrm{A} 1$ samples were obtained following the same experimental procedure. A fully deuterated $\mathrm{H}_{\mathrm{C}} \mathrm{A} 1$ control was prepared in $10 \mathrm{mM}$ Tris buffer, $150 \mathrm{mM} \mathrm{NaCl}, 8 \mathrm{M}$ uread4, pD $7.4\left(\mathrm{D}_{2} \mathrm{O} / \mathrm{H}_{2} \mathrm{O}\right.$ ratio: $\left.90 / 10 \%\right)$, incubated overnight at $20^{\circ} \mathrm{C}$ and processed as described above. All samples were prepared in triplicate for each time point and condition (independent technical replicate).

Data acquisition. Quenched samples were rapidly thawed and injected onto a nanoACQUITY UPLC M-Class system (Waters Corporation, Milford, MA) equipped with a HDX manager maintained at $0^{\circ} \mathrm{C}$ to minimize back-exchange. Labeled samples $\left(9.7 \mathrm{pmol}\right.$ of $\mathrm{H}_{\mathrm{C}} \mathrm{A} 1$ either alone or with 13.5/11 pmol of TA12/SV2C-LD) were digested using an in-house packed cartridge ( $2.0 \times 20 \mathrm{~mm}, 63 \mu \mathrm{L}$ bed volume) of immobilized pepsin beads (Thermo Scientific, Rockford, IL) for $2 \mathrm{~min}$ at $20^{\circ} \mathrm{C}$. Peptides were directly trapped and desalted onto a C18 Trap column (VanGuard BEH $1.7 \mu \mathrm{m}, 2.1$ x $5 \mathrm{~mm}$, Waters Corporation, Milford, MA) at a flow rate of 100 $\mu \mathrm{L} / \min (0.15 \%$ formic acid) and separated by a 10 min linear gradient of $5-40 \%$ acetonitrile at $40 \mu \mathrm{L} / \mathrm{min}$ using an ACQUITY UPLC BEH C18 analytical column $(1.7 \mu \mathrm{m}, 1 \times 100 \mathrm{~mm}$, Waters Corporation, Milford, MA). After each run, the pepsin column was manually cleaned with two consecutive injections of $1 \%$ formic acid, $5 \%$ acetonitrile, $1.5 \mathrm{M}$ guanidinium chloride, $\mathrm{pH}$ 1.7. Blank injections were performed between each run to confirm the absence of carry-over. Mass spectra were acquired in resolution and positive mode $(\mathrm{m} / \mathrm{z} 50-2000)$ on a Synapt G2-Si HDMS mass spectrometer (Waters Corporation, Milford, MA) equipped with a standard ESI source and lock-mass correction. Peptic peptides were identified in undeuterated 
264 samples by a combination of data independent acquisition $\left(\mathrm{MS}^{\mathrm{E}}\right)$ and exact mass measurement (below 5.0 ppm mass error) using the same chromatographic conditions than for the deuterated samples.

Data processing. The initial peptide map of $\mathrm{H}_{\mathrm{C}} \mathrm{A} 1$ was generated by database searching in ProteinLynX Global server 3.0 (Waters corporation, Milford, MA) using the following processing and workflow parameters: low and elevated intensity thresholds set to 100.0 and 50.0 counts; intensity threshold sets to 750.0 counts; automatic peptide and fragment tolerance; non-specific primary digest reagent; false discovery rate sets to $4 \%$. Each fragmentation spectrum was manually inspected for assignment confirmation. The peptide map was refined in DynamX 3.0 (Waters corporation, Milford, MA) using the following Import PLGS results filter: minimum intensity $=1500$; minimum products per amino acid $=0.4$; minimum score $=$ 6.8; maximum $\mathrm{MH}+$ error $(\mathrm{ppm})=5$; file threshold $=2$.

DynamX 3.0 was used to extract the centroid masses of all peptides selected for HDX-MS analyses. Only one unique charge state was considered per peptide and no back-exchange correction was performed. HDX results are reported as relative deuterium exchange level expressed in either mass unit or fractional exchange. Fractional exchange data were calculated by dividing the experimental uptake value by the theoretically maximum number of exchangeable backbone amide hydrogens that could be replaced into each peptide in $90 \%$ excess deuterium. MEMHDX (36) was used to visualize and statistically validate the HDX data (Wald test, false discovery rate of 5\%).

The presence of bimodal $\mathrm{m} / \mathrm{z}$ envelopes (i.e., EX1 behavior) was determined by visually inspecting the shape of the isotopic distribution for all peptides. HX-Express2 software was used to extract the uptake value of bimodal $\mathrm{m} / \mathrm{z}$ envelopes using a Double-Gaussian fitting (37).

\section{RESULTS}

\section{TA12 efficiently neutralizes BoNT/A1}

BoNT/A is divided into 8 distinct subtypes (BoNT/A1 to BoNT/A8) according to their amino acid sequence variations ranging from $2.9 \%$ to $15.6 \%$ (1). Although the BoNT/A toxinotype is defined by its neutralization with polyclonal anti-BoNT/A antibodies, each subtype can be distinctly neutralized by individual mAbs (1). We recorded that TA12 efficiently neutralized BoNT/A1 and displayed an inhibitory spectrum on BoNT/A subtypes A2, A3, and A7 (Table 1) (23). However, it showed a weak neutralizing activity against BoNT/A5 (Table
1). Taken together, these results confirm that TA12 is a highly neutralizing mAb of the most 
potent subtype BoNT/A1 with medium neutralizing activity against BoNT/A2 and A3 subtypes and low neutralizing activity against BoNT/A5 $(38,39)$.

\section{TA12 binding affinity to BoNT/A subtypes}

TA12 binding affinity to the $\mathrm{H}_{\mathrm{C}}$ domain of different BoNT/A subtypes was determined by Bio-Layer Interferometry. The binding affinity of TA12 was very high for $\mathrm{H}_{\mathrm{C}} \mathrm{A} 1, \mathrm{H}_{\mathrm{C}} \mathrm{A} 2$, and $\mathrm{H}_{\mathrm{C}} \mathrm{A} 3$ with $\mathrm{K}_{\mathrm{D}}$ values in the low $\mathrm{pM}$ range (i.e., $<100 \mathrm{pM}$; Table 2) in good agreement with previous data obtained for $\mathrm{H}_{\mathrm{C}} \mathrm{A} 1 \mathrm{using}$ Biacore instrument (24). The TA12 affinity was slightly lower with $\mathrm{H}_{C} \mathrm{~A} 2$ and significantly reduced with $\mathrm{H}_{C} \mathrm{~A} 4, \mathrm{H}_{C} \mathrm{~A}$, and $\mathrm{H}_{C} \mathrm{~A} 7$ with $\mathrm{K}_{\mathrm{D}}$ values in the low $\mathrm{nM}$ range. These differences in $\mathrm{K}_{\mathrm{D}}$ mainly result from faster dissociation rate values for $\mathrm{H}_{\mathrm{C}} \mathrm{A} 2, \mathrm{H}_{\mathrm{C}} \mathrm{A} 4, \mathrm{H}_{\mathrm{C}} \mathrm{A} 5$, and $\mathrm{H}_{\mathrm{C}} \mathrm{A} 7$ as compared to $\mathrm{H}_{\mathrm{C}} \mathrm{A} 1$. Indeed, TA12 interacts with the $\mathrm{H}_{\mathrm{C}}$ domain of the different BoNT/A subtypes with similar on-rates values (Table 2). Consistent with the protection of TA12 on BoNT/A subtypes, TA12 binds BoNT/A Hc domains with maximal affinities for BoNT/A1, A2, and A3. These results reveal that low picomolar affinities for the $\mathrm{H}_{\mathrm{C}}$ domain are required to achieve maximal TA12 neutralizing power in the mouse lethality assay.

\section{TA12 recognizes a conformational epitope at the junction between the $\mathrm{H}_{\mathrm{CC}}$ and the $\mathrm{H}_{\mathrm{CN}}$} subdomains of HCA1

To better understand the mechanism underlying BonT/A1 neutralization by TA12, the free and TA12-bound state of $\mathrm{H}_{\mathrm{C}} \mathrm{A} 1$ were subjected to HDX-MS analysis. The quench and pepsin digestions were first optimized to generate a peptide map with high sequence coverage and peptide redundancy. Urea was included in the quench buffer to favor the dissociation of the TA12: $\mathrm{H}_{\mathrm{C}} \mathrm{A} 1$ complex and increase the accessibility of both proteins to pepsin during the digestion step. A total of 98 unique peptides covering $85.2 \%$ of the $\mathrm{H}_{\mathrm{C}} \mathrm{A} 1$ sequence were confidently identified, of which 62 were selected for HDX-MS (Extended Figure 2). Overlapping peptides were only used to increase the spatial resolution when their backexchange values were similar (i.e., $<10 \%$; Extended file HDX.xls).

The binding of TA12 reduces the solvent accessibility of 12 peptides covering six distinct regions within $\mathrm{H}_{\mathrm{C}} \mathrm{Al}$ (Figure 1A, Extended Figure 3). The main decreases in solvent accessibility occur in region 2 (peptide 1005-1016; loop $\beta 31-\beta 32, \beta 32$ ), in region 4 (peptides 1114-1134, 1115-1134, 1116-1134 and 1117-1134; loop-338-loop), and in region 5 (peptides $1135-1144,1135-1147$ and $1148-1154 ; \beta 39-1 o o p-\beta 40-l o o p-\beta 41)$. Inspection of the different 
331

332

333

334

335

336

337

338

339

340

341

342

343

344

345

346

347

348

349

350

351

352

353

354

355

356

357

358

359

360

361

362

363

overlapping peptides in regions 2 and 4 reveals that the reduction of solvent accessibility is restricted to segments 1005-1009 and 1116-1124. In addition, a slight but statistically significant reduction in solvent accessibility was observed in region 1 (peptides 946-955, 946958 and 946-961; loop $\beta 27-\beta 28$ ) and in region 6 (peptide 1250-1261; $\beta 49-$-loop) (Figure 1A and Extended Figure 4A).

As shown in Figure 1B, TA12 binds $\mathrm{H}_{\mathrm{C}} \mathrm{A} 1$ at the junction between the N-terminal lectin subdomain $\left(\mathrm{H}_{\mathrm{CN}}\right)$ and the $\mathrm{C}$-terminal trefoil subdomain $\left(\mathrm{H}_{\mathrm{CC}}\right)$. The TA12 epitope appears conformational and mainly formed by the $\beta 27-\beta 28$ and $\beta 31-\beta 32$ loops of $H_{C N}$ and by the structural elements $\beta 38$ to $\beta 41, \beta 49$ and the $\beta 37-\beta 38, \beta 39-\beta 40, \beta 40-\beta 41$ and $\beta 49-\beta 50$ loops of $\mathrm{H}_{\mathrm{CC}}$. Interestingly, the HDX-MS defined TA12 epitope contains elements identified as important for the binding of both the SV2C luminal domain (SV2C-LD) and the GT1b ganglioside (Figure 1B, regions 4, 5 and 6). Indeed, the SV2C-LD binding site has been characterized in the $\mathrm{H}_{\mathrm{CN}}-\mathrm{H}_{\mathrm{CC}}$ interface and the ganglioside binding pocket in the C-terminal part of $\mathrm{H}_{\mathrm{CC}}$ (Glu1203-Gly1279 with Tyr1117 and Phe1252 playing a critical role) $(6,9,40)$. Finally, TA12 also increases the deuterium uptake in region 3 (peptide 1017-1035; $\beta 32$-loop$\beta 33$ ) in the lectin subdomain (Figures 1A, 1B). Upon complex formation, the isotopic profile of peptide 1017-1035 adopts a bimodal distribution characterized by a low and high $\mathrm{m} / \mathrm{z}$ protein population (Figure 1C). Bimodal isotopic patterns result from cooperative exchanges (also known as EX1 regime) and are very rare in proteins under physiological conditions. Several experimental factors, such as carry-over or abnormal gas-phase back-exchange are known to generate false EX1 signatures. To rule out these possibilities, a blank was acquired between each injection and the pepsin column was carefully washed after each run. In addition, specific settings were applied on the mass spectrometer (source and ion transfer) to prevent gas-phase deuterium loss (41). We are therefore confident that the bimodal pattern observed with peptide 1017-1035 is not an experimental artefact but a true change in dynamics imposed by the binding of TA12. To extract the deuterium uptake level of the low and high $\mathrm{m} / \mathrm{z}$ protein populations, the bimodal isotopic envelop was fitted with two Gaussians. The low $\mathrm{m} / z$ population showed no difference in deuterium uptake compared to free $\mathrm{H}_{\mathrm{C}} \mathrm{A} 1$ (Figure 1C). The high $\mathrm{m} / \mathrm{z}$ population however displayed an evident and constant increase in deuterium uptake over time, with the incorporation of four additional deuteriums. This data confirms that segment 1017-1035 is destabilized in the complex.

Taken together, these data reveal that TA12 targets a conformational epitope located at the junction between the $\mathrm{H}_{\mathrm{CN}}$ and $\mathrm{H}_{\mathrm{CC}}$ subdomains that overlaps with the the SV2C-LD and the 
364 GT1b binding site. The formation of the complex triggers a conformational change in the $\mathrm{H}_{\mathrm{CN}}$

365

366

367

368

369

370

371

372

373

374

375

376

377

378

379

380

381

382

383

384

385

386

387

388

389

390

391

392

393

394

395

396

397 domain that was not observed with the two previously described neutralizing antibodies ciAC2 and CR1 (see discussion) (42-45).

\section{TA12 prevents BoNT/A1 interaction with SV2C-LD}

The HDX-defined TA12 epitope overlaps with the SV2C-LD and the GT1b binding sites identified by X-ray crystallography $(6,40)$. SV2C-LD and GT1b both correspond to the neuronal cell surface receptors used by BoNT/A to efficiently and specifically enter neurons via a synergetic dual-binding process $(8,46-48)$. Based on this observation, we hypothized that TA12 binding might interfere with the interaction of both SV2C-LD and GT1b.

We first focused our attention on the $\mathrm{H}_{\mathrm{C}} \mathrm{A} 1$ :SV2C-LD interaction. The deuterium uptake profil of $\mathrm{H}_{\mathrm{C}} \mathrm{A} 1$ was monitored in the SV2C-LD:H $\mathrm{H}_{\mathrm{C}} \mathrm{A} 1$ complex and compared to the one obtained in the presence of TA12. The binding of SV2C-LD induced several statistically significant changes (Wald test, $p<0.05$ ) in deuterium uptake in $\mathrm{H}_{\mathrm{C}} \mathrm{A} 1$ (Figure 2A; Extended Figures 4B, 5). As observed in the $\mathrm{H}_{\mathrm{C}} \mathrm{A} 1$ :TA12 complex, major reductions were observed in region 2 of the $\mathrm{H}_{\mathrm{CC}}$ domain (peptides 1145-1154 and 1148-1154, region 5 in Figure 1) covering loops $\beta 39-\beta 40$ and $\beta 40-\beta 41$. Region 2 corresponds to the main SV2C-LD interaction site identified by X-ray crystallography and contains critical residues for binding such as T1145 and T1146 (Figures 2B) $(6,10)$. Therefore, these data confirm that TA12 and SV2C both target a common binding region on $\mathrm{H}_{\mathrm{C}} \mathrm{A} 1$ (Compare Figures 1A, 1B and 2A, 2B). Two additional regions surrounding residues 1145-1154, namely region 1 (peptides 946-955, 946-958 and 946961 ) in the $\mathrm{H}_{\mathrm{CN}}$ domain and region 3 (peptides 1282-1296, 1283-1296, 1284-1296 and 12851296) in the C-terminal part of $\mathrm{H}_{\mathrm{CC}}$, also display minor but statistically significant reductions in uptake upon complex formation. Region 3 contains several overlapping peptides with similar back-exchange values (Extended file HDX.xls) allowing to confine the effects of SV2C-LD binding to segment 1285-1296 only. This segment contains residue R1294 involved in the interaction and the binding specificity with SV2C-LD. Finally, although region 1 is very close to the main SV2C-LD interaction site (i.e., region 2), this latter was not identified as part of the SV2C-LD binding interface by X-ray crystallography (Figure 2B). Based on this observation, the slight decrease in solvent accessibility observed in 946-961 might be attributed to a change in dynamics rather than a masking effect.

We next performed in vitro experiments to analyze the interference of TA12 on the binding of recombinant $\mathrm{H}_{\mathrm{C}} \mathrm{A} 1$ to $\mathrm{SV} 2 \mathrm{C}-\mathrm{LD}$ immobilized on glutathione-Sepharose 4B beads. As shown in Figure 2C, $\mathrm{H}_{\mathrm{C}} \mathrm{A} 1$ binding to immobilized SV2C-LD was prevented in a TA12 dose- 
398

399

400

401

402

403

404

405

406

407

408

409

410

411

412

413

414

415

416

417

418

419

420

421

422

423

424

425

426

427

428

429

430

431

dependent manner. More than $90 \%$ inhibition of binding was obtained at an equimolar ratio between TA12 and $\mathrm{H}_{\mathrm{C}} \mathrm{A} 1$. These results confirm that TA12 prevents the formation of the toxin/receptor complex via direct interaction with $\mathrm{H}_{\mathrm{C}} \mathrm{A} 1$. Thus, as observed with the neutralizing ciA-C2 VHH, TA12 blocks the entry of BoNT/A1 into neuronal cells by targeting one critical area of the toxin-cell receptor interface.

\section{TA12 affects HCA1 binding to GT1b}

We next focused our attention on the $\mathrm{H}_{\mathrm{C}} \mathrm{Al}$ :GT1b interaction. Our HDX-MS data shows that TA12 affects the solvent accessibility of elements involved in the GT1b-binding site (Figure 3A). Region 1116-1124 contains residue Y1117 which directly coordinates GT1b through hydrogen bondings with sialic acid 5 (Sia5); residue F1252 in region 1250-1252 also hydrogen bonds to galactose 4 (Gal4) of the GT1b ganglioside (40). Compared to SV2C-LD, GT1b only shares a limited overlapping binding area with TA12 on $\mathrm{H}_{\mathrm{C}} \mathrm{A} 1$ (Figure 3A). Therefore, TA12 is not expected to directly compete with GT1b binding on $\mathrm{H}_{\mathrm{CA}} \mathrm{A}$ as observed with SV2C-LD but rather to affect the $\mathrm{H}_{\mathrm{C}} \mathrm{A} 1$ :GT1b interaction mainly through steric clashes.

To determine the effects of TA12 on $\mathrm{H}_{\mathrm{CA}} 1$ binding to GT1b, an inhibition binding assay was performed using GT1b coated on plastic plate and incubated with $\mathrm{H}_{\mathrm{C}} \mathrm{A} 1$ either alone or in the presence of TA12. A shown in Figure 3B, increased concentrations of TA12 result in inhibition of $\mathrm{H}_{\mathrm{C}} \mathrm{A} 1$ binding to GT1b. Complete inhibition of $\mathrm{H}_{\mathrm{C}} \mathrm{A} 1$ binding to GT1b was achieved at a much higher TA12/H $\mathrm{HA} 1$ molar ratio compared to SV2C-LD (10:1 for GT1b; 1:1 for SV2C-LD), hence suggesting that TA12 mainly causes indirect interferences with GT1b. Altogether, these data confirm that TA12 is also able to interefere with $\mathrm{H}_{\mathrm{C}} \mathrm{A} 1$ binding to GT1b abeit with a lower efficiency compared to the binding inhibition of HcA1 to SV2C-LD.

\section{Residue N1006 is important for TA12 binding.}

Although TA12 recognizes the $\mathrm{H}_{\mathrm{C}}$ domain of BoNT/A subtypes with high affinity (i.e., in the low pM-nM range; Table 2), the efficiency of neutralization appears subtype dependent. The quantity of TA12 required to neutralize $50 \%$ of the activity of both BoNT/A5 and A7 appears 400- and 40-fold higher than for BoNT/A1, respectively (Table 1). Interestingly, the $\mathrm{H}_{\mathrm{C}}$ domain of BoNT/A1 shares respectively 94.1 and $91.7 \%$ sequence identity with $\mathrm{H}_{\mathrm{C}} \mathrm{A} 5$ and $\mathrm{H}_{\mathrm{C}} \mathrm{A} 7$, suggesting that small variations in the primary sequence are sufficient to explain the difference of neutralizing potency by TA12. To test this hypothesis, specific residues mainly positioned within the HDX-MS defined TA12 epitope where major changes in deuterium uptake occur upon binding were selected for substitution (Extended Figure 6). Four distinct 
432 residues of $\mathrm{H}_{\mathrm{C}} \mathrm{A} 1$ including N1006 (region 2, Figure 1), and V1143, M1144 and R1156 (region

4335 , Figure 1) were replaced by the corresponding residues found in $\mathrm{H}_{\mathrm{C}} \mathrm{A} 5$ or $\mathrm{H}_{\mathrm{C}} \mathrm{A}$ 7. The 434 modified residues correspond to natural $\mathrm{H}_{\mathrm{C}}$ variants and their mutation is therefore not expected 435 to cause any local secondary structural changes on $\mathrm{H}_{\mathrm{C}} \mathrm{A} 1$. The substitution of V1143 alone or 436 in combination with M1144 and R1156 showed no significant effect on TA12 binding (Table

437 2). By contrast, the substitution of N1006 with alanine strongly affects the binding of TA12 to $438 \mathrm{H}_{\mathrm{C}} \mathrm{A} 1$ with a 280 -fold reduction in affinity compared to wild type (Table 2 ) confirming the 439 importance of N1006 in complex formation.

440

\section{DISCUSSION}

442 Neutralizing antibodies against BoNT represent the only available antidote against 443 botulism considering that vaccination is not an appropriate strategy due to the expanding 444 therapeutic applications of BoNTs. Although equine anti-BoNT polyclonal sera are able to 445 efficiently neutralize all seven known BoNT toxinotypes, their use can cause dramatic side 446 effects $(13,49-53)$. Alternative therapeutic antitoxin approaches, such as mAbs or peptide 447 inhibitors (6), are currently explored to reduce the risks of serum sickness and cardiac arrest. 448 Human anti-BoNT immune globulins obtained from vaccinated donors have been developed 449 for the treatment of infant botulism, but their production is not easily scalable (14). 450 Recombinant $\mathrm{mAbs}$ and more specially recombinant humanized mAbs represent a promising 451 and safer alternative strategy for botulism treatment. Their production is highly reproducible 452 compared to animal hyperimmune sera thereby preventing batch to batch variations in antibody 453 affinity (50). Over the last decade, several neutralizing mAbs against the distinct BoNT types 454 have been generated $(17,18,54)$. However, mAbs are specific of single epitopes only and extended protective coverage most often requires the combination of several mAbs. For example, the association of three distinct mAbs targeting non-overlapping epitopes of BoNT/A was found to be highly protective, whereas each single mAb showed no significant protection.

458 Moreover, the three $\mathrm{mAb}$ in combination induced a 90-fold greater neutralizing potency of 459 BoNT/A than human hyperimmune globulins (21). Altough effective to treat botulism, the 460 association of several $\mathrm{mAbs}$ introduces unique development and manufacturing challenges for 461 clinical application. Recentlty, a single tri-epitopic IgG1-based mAb ( $\mathrm{TeAb}$ ) containing the 462 binding sites of three individual anti-BoNT/A1 mAbs was engineered (22). TeAb was found to 463 be much more potent in mouse-neutralization assay than any of the three single mAbs and 464 almost as potent as the combination of the three individual mAbs against BoNT/A1. Though 
465

466

467

468

469

470

471

472

473

474

475

476

477

478

479

480

481

482

483

484

485

486

487

488

489

490

491

492

493

494

495

496

497

498

the neutralization potency of $\mathrm{TeAb}$ against the other BoNT/A subtypes was not reported, this work highlights the potential of using single mAbs as alternative antitoxin solution (22).

In this study, we showed that the single TA12 mAb raised against $\mathrm{H}_{\mathrm{CA}} \mathrm{l}$ is a potent inhibitor of the two most frequent subtypes involved in human botulism, namely A1 and A2 (55-57), but also A3. TA12 recognizes a conformational epitope mainly composed of solvent accessible loops located at the interface between the $\mathrm{H}_{\mathrm{CN}}$ and the $\mathrm{H}_{\mathrm{CC}}$ subdomain. The TA12 binding site overlaps with both the SV2C and the GT1b binding interfaces on $\mathrm{H}_{\mathrm{C}} \mathrm{A} 1$, causing interferences with the interaction of the two neuronal cell surface receptors used by BonT/A to enter neutrons. The strong neutralization potency of TA12 is therefore achieved by the synergetic and simultaneous inhibition of BoNT/A binding to GT1b and the peptide moiety of the SV2C luminal domain.

Two additional BoNT/A neutralizing antibodies have been reported to block the recognition of SV2C: the camelid single domain ciA-C2 antibody $(42,43)$ and the human monoclonal antibody CR1 currently in clinical trials $(44,45)$. The identification of the TA12 binding site provides a means to compare the different epitopes on $\mathrm{H}_{\mathrm{C}} \mathrm{A} 1$ and the neutralization mechanism of each antibody. All three antibodies target the same $\mathrm{H}_{\mathrm{CN}} / \mathrm{H}_{\mathrm{CC}}$ junction, which was shown to elicit neutralizing antibodies against BoNT/A (28), but they adopt distinct orientation on $\mathrm{H}_{\mathrm{C}} \mathrm{Al}$ (Figure 4). CR1 mainly occupies the SV2C glycan binding site on the $\mathrm{H}_{\mathrm{CN}}$ subdomain. The CR1 epitope locates on the same $\mathrm{H}_{\mathrm{C}} \mathrm{Al}$ 's face than the glycosylated SV2C (gSV2C) without sharing any overlapping peptide regions with gSV2C. The large size of CR1 and its close proximity with gSV2C are sufficient to generate local steric clashes between portions of $\mathrm{CR} 1$ and $\mathrm{gSV} 2 \mathrm{C}$, causing indirect interferences with gSV2C binding on $\mathrm{H}_{\mathrm{C}} \mathrm{A} 1$ (10, 45). The strong neutralizing potency of CR1 is therefore driven by two simulatenous blocking effects: an indirect effect with the SV2C peptides moieties and a direct effect through the occupation of the SV2C glycan binding site. As observed with CR1, ciA-C2 largely occupies the binding site for the $\mathrm{SV} 2 \mathrm{C}$ glycan but it also interacts with a key region in the $\mathrm{H}_{\mathrm{CN}}$ subdomain containing critical residues for gSV2C binding (Figure 4). Thus, ciA-C2 simulatenously inhibits both the protein- and the glycan- interactions between BonT/A1 and gSV2C via direct blocking effects (43). The TA12 epitope shares common structural features with ciA-C2 as they both occupy the same gSV2C peptide binding site on $\mathrm{H}_{\mathrm{C}} \mathrm{A} 1$ and directly block gSV2C binding to BoNT/A (Figure 4). However, the TA12 binding interface lies on the face opposite recognized by both ciA-C2 and $\mathrm{CR} 1$, confirming that the $\mathrm{H}_{\mathrm{CN}} / \mathrm{H}_{\mathrm{CC}}$ junction contains distinct antigenic regions able to elicit highly potent and unique BoNT/A neutralizing antibodies (28). 
499 In contrast to both ciA-C2 and CR1, TA12 does not compete with the SV2C glycan but 500 interferes with $\mathrm{H}_{\mathrm{C}} \mathrm{A} 1$ binding to GT1b.

501 The identification of the TA12 epitope on BoNT/A also provides a means to understand 502 the variations in potency observed with the different $\mathrm{H}_{\mathrm{C}} \mathrm{A}$ subtypes (Tables 1, 2). The three 503 main regions defining the TA12 epitope (i.e., I1005-D1009, Y1117-V1125, and L1136-L1154; 504 Extended Figure 6) are relatively well conserved hence explaining the capabilities of TA12 to 505 recognize all $\mathrm{H}_{\mathrm{C}} \mathrm{A}$ subtypes with high affinity. As previously reported, the antitoxin efficacy of 506 antibodies largely depends on their binding affinity (42). Thereby, the highest TA12 binding 507 affinities and neutralization potencies were obtained with subtypes A1, A3 and A2 whereas the 508 lowest were observed with A5 and A7. TA12 binds A5 and A7 with affinity values comparable to both ciA-C2 and CR1 (i.e, in the low nanomolar range), and yet only poorly neutralizes BoNT/A5 in the mouse lethality assay. Low nanomolar $K_{D}$ are therefore not sufficient because TA12 interferes simultaenously with the two BoNT/A cell binding partners. The unique neutralization mechanism of TA12 requires therefore low picomolar range affinity to prevent 513 the deplacement of the bound antibody from the toxin by either gSV2C, GT1b or both. We believe therefore that the differences in potency observed between $\mathrm{H}_{\mathrm{C}} \mathrm{A}$ subtypes are due to subtle amino-acid changes within the TA12 binding interface, resulting in lower $\mathrm{K}_{\mathrm{D}}$ values, as we showed with residue 1006 in $\mathrm{H}_{C} \mathrm{~A} 5$. In addition, TA12 interferes on $\mathrm{H}_{\mathrm{C}} \mathrm{A} 1$ interaction with gangliosides. Albeit TA12 prevented $\mathrm{H}_{\mathrm{C}} \mathrm{A} 1$ binding to GT1b with lower efficiency compared to SV2C-LD, the cumulative effect of TA12 on binding to both types of $\mathrm{H}_{\mathrm{C}} \mathrm{A} 1$ cell receptors likely contributes to the highly efficient in vivo neutralization observed in mouse protection assay. To our knowledge, TA12 is the first antibody able to neutralize BoNT/A by simultaneously interfering with the binding to the two cell surface receptor types on motoneurons.

\section{Acknowledgements}

525 We thank UtechS MSBio of Institut Pasteur for the access to the HDX-MS instrumentation. 526 The CACSICE Equipex ANR-11-EQPX-0008 is acknowledged.

\section{Author contributions}

529 M.R.P. designed the project. S.B., M.R.P, CRE, AW, SS, MM, designed and performed the experiments. S.B., M.R.P and CRE analyzed the data. S.B. and M.R.P. wrote the manuscript. All authors discussed and commented on the manuscript. 


\section{REFERENCES}

535

536

1. Peck, M. W., Smith, T. J., Anniballi, F., Austin, J. W., Bano, L., Bradshaw, M., Cuervo, P., Cheng, L. W., Derman, Y., Dorner, B. G., Fisher, A., Hill, K. K., Kalb, S. R., Korkeala, H., Lindstrom, M., Lista, F., Luquez, C., Mazuet, C., Pirazzini, M., Popoff, M. R., Rossetto, O., Rummel, A., Sesardic, D., Singh, B. R., and Stringer, S. C. (2017) Historical Perspectives and Guidelines for Botulinum Neurotoxin Subtype Nomenclature. Toxins (Basel) 9, 38

542

2. Poulain, B., and Popoff, M. R. (2019) Why Are Botulinum Neurotoxin-Producing Bacteria So Diverse and Botulinum Neurotoxins So Toxic? Toxins (Basel). 11(1). toxins11010034. doi: 11010010.11013390/toxins11010034.

3. Arnon, S. S., Schechter, R., Inglesby, T. V., Henderson, D. A., Bartlett, J. G., Ascher, M. S., Eitzen, E., Fine, A. D., Hauer, J., Layton, M., Lillibridge, S., Osterholm, M. T., O'Toole, T., Parker, G., Perl, T. M., Russell, P. K., Swerdlow, D. L., and Tonat, K. (2001) Botulinum toxin as a biological weapon: medical and public health management. JAMA 285, 1059-1070

4. Poulain, B., Molgo, J., and Popoff, M. R. (2015) Clostridial neurotoxins: from the cellular and molecular mode of action to their therapeutic use. In The Comprehensive Sourcebook of Bacterial Protein Toxins (Alouf, J., Ladant, D., and Popoff, M. R., eds) pp. 287-336, Elsevier, Amsterdam

5. Rossetto, O., Pirazzini, M., and Montecucco, C. (2014) Botulinum neurotoxins: genetic, 555 structural and mechanistic insights. Nat Rev Microbiol. 12, 535-549. doi: $510.1038 /$ nrmicro3295.

6. Benoit, R. M., Frey, D., Hilbert, M., Kevenaar, J. T., Wieser, M. M., Stirnimann, C. U., McMillan, D., Ceska, T., Lebon, F., Jaussi, R., Steinmetz, M. O., Schertler, G. F., recognition of synaptic vesicle protein $2 \mathrm{C}$ by botulinum neurotoxin A. Nature. $\mathbf{5 0 5}, 108$ 111. doi: 110.1038/nature12732. 
565

566

567

568

569

570

571

572

573

574

575

576

577

578

579

580

581

582

583

584

585

586

587

588

589

590

591

592

593

594

595

596

597

598

8. Mahrhold, S., Rummel, A., Bigalke, H., Davletov, B., and Binz, T. (2006) The synaptic vesicle protein $2 \mathrm{C}$ mediates the uptake of botulinum neurotoxin A into phrenic nerves. FEBS Lett 580, 2011-2014

9. Rummel, A., Mahrhold, S., Bigalke, H., and Binz, T. (2004) The $\mathrm{H}_{\mathrm{cc}}$-domain of botulinum neurotoxins A and B exhibits a singular ganglioside binding site displaying serotype specific carbohydrate interaction. Mol. Microbiol. 51, 631-643

10. Yao, G., Zhang, S., Mahrhold, S., Lam, K. H., Stern, D., Bagramyan, K., Perry, K., Kalkum, M., Rummel, A., Dong, M., and Jin, R. (2016) N-linked glycosylation of SV2 is required for binding and uptake of botulinum neurotoxin A. Nat Struct Mol Biol 23, 656662

11. Yowler, B. C., Kensinger, R. D., and Schengrund, C. L. (2002) Botulinum neurotoxin A activity is dependent upon the presence of specific gangliosides in neuroblastoma cells expressing synaptotagmin I. J. Biol. Chem. 277, 32815-32819

12. Black, R. E., and Gunn, R. A. (1980) Hypersensitivity reactions associated with botulinal antitoxin. Am J Med. 69, 567-570. doi: 510.1016/0002-9343(1080)90469-90466.

13. Schussler, E., Sobel, J., Hsu, J., Yu, P., Meaney-Delman, D., Grammer, L. C., 3rd, and Nowak-Wegrzyn, A. (2017) Workgroup Report by the Joint Task Force Involving American Academy of Allergy, Asthma \& Immunology (AAAAI); Food Allergy, Anaphylaxis, Dermatology and Drug Allergy (FADDA) (Adverse Reactions to Foods Committee and Adverse Reactions to Drugs, Biologicals, and Latex Committee); and the Centers for Disease Control and Prevention Botulism Clinical Treatment Guidelines Workgroup-Allergic Reactions to Botulinum Antitoxin: A Systematic Review. Clin Infect Dis. 66, S65-S72. doi: 10.1093/cid/cix1827.

14. Arnon, S. S., Schechter, R., Maslanka, S. E., Jewell, N. P., and Hatheway, C. L. (2006) Human botulism immune globulin for the treatment of infant botulism. $N$ Engl J Med 354, $462-471$

15. Khouri, J. M., Motter, R. N., and Arnon, S. S. (2018) Safety and immunogenicity of investigational recombinant botulinum vaccine, $\mathrm{rBV} \mathrm{A} / \mathrm{B}$, in volunteers with pre-existing botulinum toxoid immunity. Vaccine. 36, 2041-2048. doi:

2010.1016/j.vaccine.2018.2002.2042.

16. Nayak, S. U., Griffiss, J. M., McKenzie, R., Fuchs, E. J., Jurao, R. A., An, A. T., Ahene, A., Tomic, M., Hendrix, C. W., and Zenilman, J. M. (2014) Safety and pharmacokinetics of XOMA $3 \mathrm{AB}$, a novel mixture of three monoclonal antibodies against botulinum toxin A. Antimicrob Agents Chemother. 58, 5047-5053. doi: 5010.1128/AAC.02830-02814. 
599

600

601

602

603

604

605

606

607

608

609

610

611

612

613

614

615

616

617

618

619

620

621

622

623

624

625

626

627

628

629

630

631

632

17. Rasetti-Escargueil, C., Avril, A., Miethe, S., Mazuet, C., Derman, Y., Selby, K., Thullier, P., Pelat, T., Urbain, R., Fontayne, A., Korkeala, H., Sesardic, D., Hust, M., and Popoff, M. R. (2017) The European AntibotABE Framework Program and Its Update: Development of Innovative Botulinum Antibodies. Toxins (Basel) 9, 309. doi: $10.3390 /$ toxins 9100309

18. Lou, J., and Marks, J. D. (2018) Botulinum Neurotoxins (BoNTs)-Antibody and Vaccine. Toxins (Basel). 10(12). toxins 10120495. doi: 10120410.10123390/toxins10120495.

19. Fan, Y., Garcia-Rodriguez, C., Lou, J., Wen, W., Conrad, F., Zhai, W., Smith, T. J., Smith, L. A., and Marks, J. D. (2017) A three monoclonal antibody combination potently neutralizes multiple botulinum neurotoxin serotype F subtypes. PLoS One 12, e0174187

20. Garcia-Rodriguez, C., Razai, A., Geren, I. N., Lou, J., Conrad, F., Wen, W. H., FarrJones, S., Smith, T. J., Brown, J. L., Skerry, J. C., Smith, L. A., and Marks, J. D. (2018) A Three Monoclonal Antibody Combination Potently Neutralizes Multiple Botulinum Neurotoxin Serotype E Subtypes. Toxins (Basel) 10, doi: 10.3390/toxins10030105

21. Nowakowski, A., Wang, C., Powers, D. B., Amersdorfer, P., Smith, T. J., Montgomery, V. A., Sheridan, R., Blake, R., Smith, L. A., and Marks, J. D. (2002) Potent neutralization of botulinum neurotoxin by recombinant oligoclonal antibody. Proc. Ntl. Acad. Sci. (USA) 99, 11346-11350

22. Lou, J., Wen, W., Conrad, F., Meng, Q., Dong, J., Sun, Z., Garcia-Rodriguez, C., FarrJones, S., Cheng, L. W., Henderson, T. D., Brown, J. L., Smith, T. J., Smith, L. A., Cormier, A., and Marks, J. D. (2018) A Single Tri-Epitopic Antibody Virtually Recapitulates the Potency of a Combination of Three Monoclonal Antibodies in Neutralization of Botulinum Neurotoxin Serotype A. Toxins (Basel) 10, 84. doi: $10.3390 /$ toxins 10020084

23. Mazuet, C., Dano, J., Popoff, M. R., Creminon, C., and Volland, H. (2010) Characterization of botulinum neurotoxin type A neutralizing monoclonal antibodies and influence of their half-lives on therapeutic activity. PLoS One 5, e12416

24. Prigent, J., Mazuet, C., Boquet, D., Lamourette, P., Volland, H., Popoff, M. R., Creminon, C., and Simon, S. (2010) Production and characterisation of a neutralising chimeric antibody against botulinum neurotoxin A. PLoS One 5, e13245

25. Brier, S., Le Mignon, M., Jain, K., Lebrun, C., Peurois, F., Kellenberger, C., Bordas-Le Floch, V., Mascarell, L., Nony, E., and Moingeon, P. (2018) Characterization of epitope specificities of reference antibodies used for the quantification of the birch pollen allergen Bet v 1. Allergy. 73, 1032-1040. doi: 1010.1111/all.13364. 
633

634

635

636

637

638

639

640

641

642

643

644

645

646

647

648

649

650

651

652

653

654

655

656

657

658

659

660

661

662

663

664

665

666

26. Brier, S., Lemaire, D., DeBonis, S., Kozielski, F., and Forest, E. (2006) Use of hydrogen/deuterium exchange mass spectrometry and mutagenesis as a tool to identify the binding region of inhibitors targeting the human mitotic kinesin Eg5. Rapid Commun Mass Spectrom 20, 456-462. doi: 410.1002/rcm.2329.

27. Volland, H., Lamourette, P., Nevers, M. C., Mazuet, C., Ezan, E., Neuburger, L. M., Popoff, M., and Creminon, C. (2008) A sensitive sandwich enzyme immunoassay for free or complexed Clostridium botulinum neurotoxin type A. J Immunol Methods 330, 120129

28. Tavallaie, M., Chenal, A., Gillet, D., Pereira, Y., Manich, M., Gibert, M., Raffestin, S., Popoff, M. R., and Marvaud, J. C. (2004) Interaction between the two subdomains of the C-terminal part of the botulinum neurotoxin A is essential for the generation of protective antibodies. FEBS Lett. 572, 299-306

29. Couesnon, A., Molgo, J., Connan, C., and Popoff, M. R. (2012) Preferential entry of botulinum neurotoxin A Hc domain trhough intestinal crypt cells and targeting to cholinergic neurons of the mouse intestine. PLoS Pathog 8, e1002583

30. Burns, J. R., Lambert, G. S., and Baldwin, M. R. (2017) Insights into the Mechanisms by Which Clostridial Neurotoxins Discriminate between Gangliosides. Biochemistry. 56, 2571-2583. doi: 2510.1021/acs.biochem.2576b01246.

31. Karalewitz, A. P., Kroken, A. R., Fu, Z., Baldwin, M. R., Kim, J. J., and Barbieri, J. T. (2010) Identification of a unique ganglioside binding loop within botulinum neurotoxins C and D-SA. Biochemistry 49, 8117-8126

32. Strotmeier, J., Gu, S., Jutzi, S., Mahrhold, S., Zhou, J., Pich, A., Eichner, T., Bigalke, H., Rummel, A., Jin, R., and Binz, T. (2011) The biological activity of botulinum neurotoxin type $\mathrm{C}$ is dependent upon novel types of ganglioside binding sites. Mol Microbiol 81, 143-156

33. Malizio, C. J., Goodnough, M. C., and Johnson, E. A. (2000) Purification of Clostridium botulinum type A neurotoxin. Methods Mol Biol 145, 27-39

34. Rasetti-Escargueil, C., Avril, A., Chahboun, S., Tierney, R., Bak, N., Miethe, S., Mazuet, C., Popoff, M. R., Thullier, P., Hust, M., Pelat, T., and Sesardic, D. (2015) Development of human-like scFv-Fc antibodies neutralizing Botulinum toxin serotype B. MAbs 7, 1161-1177

35. Masson, G. R., Burke, J. E., Ahn, N. G., Anand, G. S., Borchers, C., Brier, S., Bou-Assaf, G. M., Engen, J. R., Englander, S. W., Faber, J., Garlish, R., Griffin, P. R., Gross, M. L., Guttman, M., Hamuro, Y., Heck, A. J. R., Houde, D., Iacob, R. E., Jorgensen, T. J. D., 
667

668

669

670

671

672

673

674

675

676

677

678

679

680

681

682

683

684

685

686

687

688

689

690

691

692

693

694

695

696

697

698

Kaltashov, I. A., Klinman, J. P., Konermann, L., Man, P., Mayne, L., Pascal, B. D., Reichmann, D., Skehel, M., Snijder, J., Strutzenberg, T. S., Underbakke, E. S., Wagner, C., Wales, T. E., Walters, B. T., Weis, D. D., Wilson, D. J., Wintrode, P. L., Zhang, Z., Zheng, J., Schriemer, D. C., and Rand, K. D. (2019) Recommendations for performing, interpreting and reporting hydrogen deuterium exchange mass spectrometry (HDX-MS) experiments. Nat Methods. 16, 595-602. doi: 510.1038/s41592-41019-40459-y.

36. Hourdel, V., Volant, S., O'Brien, D. P., Chenal, A., Chamot-Rooke, J., Dillies, M. A., and Brier, S. (2016) MEMHDX: an interactive tool to expedite the statistical validation and visualization of large HDX-MS datasets. Bioinformatics. 32, 3413-3419. doi: 3410.1093/bioinformatics/btw3420. Epub 2016 Jul 3413.

37. Guttman, M., Weis, D. D., Engen, J. R., and Lee, K. K. (2013) Analysis of overlapped and noisy hydrogen/deuterium exchange mass spectra. J Am Soc Mass Spectrom. 24, 1906-1912. doi: 1910.1007/s13361-13013-10727-13365.

38. Pellett, S., Tepp, W. H., Whitemarsh, R. C., Bradshaw, M., and Johnson, E. A. (2015) In vivo onset and duration of action varies for botulinum neurotoxin A subtypes 1-5. Toxicon 107, 37-42

39. Whitemarsh, R. C., Tepp, W. H., Bradshaw, M., Lin, G., Pier, C. L., Scherf, J. M., Johnson, E. A., and Pellett, S. (2013) Characterization of botulinum neurotoxin A subtypes 1 through 5 by investigation of activities in mice, in neuronal cell cultures, and in vitro. Infect Immun. 81, 3894-3902. doi: 3810.1128/IAI.00536-00513.

40. Stenmark, P., Dupuy, J., Imamura, A., Kiso, M., and Stevens, R. C. (2008) Crystal structure of botulinum neurotoxin type A in complex with the cell surface co-receptor GT1b-insight into the toxin-neuron interaction. PLoS Pathog 4, e1000129

41. Guttman, M., Wales, T. E., Whittington, D., Engen, J. R., Brown, J. M., and Lee, K. K. (2016) Tuning a High Transmission Ion Guide to Prevent Gas-Phase Proton Exchange During H/D Exchange MS Analysis. J Am Soc Mass Spectrom. 27, 662-668. doi: 610.1007/s13361-13015-11330-13368.

42. Mukherjee, J., Tremblay, J. M., Leysath, C. E., Ofori, K., Baldwin, K., Feng, X., Bedenice, D., Webb, R. P., Wright, P. M., Smith, L. A., Tzipori, S., and Shoemaker, C. B. (2012) A novel strategy for development of recombinant antitoxin therapeutics tested in a mouse botulism model. PLoS One 7, e29941. doi: 29910.21371/journal.pone.0029941. 
699

700

701

702

703

704

705

706

707

708

709

710

711

712

713

714

715

716

717

718

719

720

721

722

723

724

725

726

727

728

729

730

731

43. Yao, G., Lam, K. H., Weisemann, J., Peng, L., Krez, N., Perry, K., Shoemaker, C. B., Dong, M., Rummel, A., and Jin, R. (2017) A camelid single-domain antibody neutralizes botulinum neurotoxin A by blocking host receptor binding. Sci Rep 7, 7438

44. Garcia-Rodriguez, C., Geren, I. N., Lou, J., Conrad, F., Forsyth, C., Wen, W., Chakraborti, S., Zao, H., Manzanarez, G., Smith, T. J., Brown, J., Tepp, W. H., Liu, N., Wijesuriya, S., Tomic, M. T., Johnson, E. A., Smith, L. A., and Marks, J. D. (2011) Neutralizing human monoclonal antibodies binding multiple serotypes of botulinum neurotoxin. Protein Eng Des Sel. 24, 321-331. doi: 310.1093/protein/gzq1111.

45. Garcia-Rodriguez, C., Levy, R., Arndt, J. W., Forsyth, C. M., Razai, A., Lou, J., Geren, I., Stevens, R. C., and Marks, J. D. (2007) Molecular evolution of antibody crossreactivity for two subtypes of type A botulinum neurotoxin. Nat Biotechnol. 25, 107-116. doi: $110.1038 / \mathrm{nbt} 1269$.

46. Dong, M., Yeh, F., Tepp, W. H., Dean, C., Johnson, E. A., Janz, R., and Chapman, E. R. (2006) SV2 Is the Protein Receptor for Botulinum Neurotoxin A. Science 312, 592-596

47. Kozaki, S., Kamata, Y., Watarai, S., Nishiki, T., and Mochida, S. (1998) Ganglioside GT1b as a complementary receptor component for Clostridium botulinum neurotoxins. Microbiol. Pathol. 25, 91-99

48. Yowler, B. C., and Schengrund, C. L. (2004) Botulinum neurotoxin A changes conformation upon binding to ganglioside GT1b. Biochemistry 43, 9725-9731

49. Hifumi, T., Yamamoto, A., Ato, M., Sawabe, K., Morokuma, K., Morine, N., Kondo, Y., Noda, E., Sakai, A., Takahashi, J., and Umezawa, K. (2017) Clinical Serum Therapy: Benefits, Cautions, and Potential Applications. Keio J Med. 66, 57-64. doi: 10.2302/kjm.2016-0017-IR.

50. Thanongsaksrikul, J., and Chaicumpa, W. (2011) Botulinum neurotoxins and botulism: a novel therapeutic approach. Toxins (Basel). 3, 469-488. doi: 410.3390/toxins3050469. Epub 3052011 May 3050413.

51. Hill, S. E., Iqbal, R., Cadiz, C. L., and Le, J. (2013) Foodborne botulism treated with heptavalent botulism antitoxin. Ann Pharmacother. 47, e12. doi: 10.1345/aph.1341R1646.

52. Hibbs, R. G., Weber, J. T., Corwin, A., Allos, B. M., Abd el Rehim, M. S., Sharkawy, S. E., Sarn, J. E., and McKee, K. T., Jr. (1996) Experience with the use of an investigational $\mathrm{F}\left(\mathrm{ab}^{\prime}\right) 2$ heptavalent botulism immune globulin of equine origin during an outbreak of type E botulism in Egypt. Clin Infect Dis 23, 337-340 
732 53. Yu, P. A., Lin, N. H., Mahon, B. E., Sobel, J., Yu, Y., Mody, R. K., Gu, W., Clements, J., 733 Kim, H. J., and Rao, A. K. (2017) Safety and Improved Clinical Outcomes in Patients 734 Treated With New Equine-Derived Heptavalent Botulinum Antitoxin. Clin Infect Dis. 66, 735 S57-S64. doi: 10.1093/cid/cix1816.

736 54. Marks, J. D. (2004) Deciphering antibody properties that lead to potent botulinum 737 neurotoxin neutralization. Mov Disord 19 Suppl 8, S101-108

738 55. Carter, A. T., and Peck, M. W. (2015) Genomes, neurotoxins and biology of Clostridium 739 botulinum Group I and Group II. Res Microbiol 166, 303-317

740 56. Mazuet, C., Legeay, C., Sautereau, J., Ma, L., Bouchier, C., Bouvet, P., and Popoff, M.

741 R. (2016) Diversity of Group I and II Clostridium botulinum Strains from France

742 Including Recently Identified Subtypes. Genome Biol Evol 8, 1643-1660

743 57. Williamson, C. H., Sahl, J. W., Smith, T. J., Xie, G., Foley, B. T., Smith, L. A.,

744 Fernandez, R. A., Lindstrom, M., Korkeala, H., Keim, P., Foster, J., and Hill, K. (2016)

745 Comparative genomic analyses reveal broad diversity in botulinum-toxin-producing

$746 \quad$ Clostridia. BMC Genomics 17, 180 
Figure 1 Effects of TA12 binding on the deuterium uptake behavior of HCA1. A, The

751 fractional uptake difference plot was generated for each peptide and at each time point by 752 subtracting the deuterium uptake values in the TA12-unbound from those in the bound state. 753 Positive numbers indicate TA12-induced protection (regions 1, 2, 4, 5 and 6) while negative 754 values indicate an increase in solvent accessibility (region 3). The six regions displaying 755 statistically significant changes of deuterium uptake upon TA12 binding (Wald test, $p<0.05$ ) 756 are highlighted in gray. Each dot corresponds to an average of three independent replicates. B, 757 Mapping of the HDX-MS results obtained after $60 \mathrm{~min}$ labeling onto the cartoon and surface 758 representations of $\mathrm{H}_{\mathrm{CA}} \mathrm{A}$ ( $\mathrm{pdb} \#$ 2NZ9). The largest reductions of deuterium uptake mainly 759 occur within loops (regions 2, 4 and 5) located at the interface between the N-terminal lectin 760 subdomain $\left(\mathrm{H}_{\mathrm{CN}}\right)$ and the $\mathrm{C}$-terminal trefoil subdomain $\left(\mathrm{H}_{\mathrm{CC}}\right)$ whereas changes in dynamics are 761 observed in $\mathrm{H}_{\mathrm{CN}}$ only. "No change" refers to regions of $\mathrm{H}_{\mathrm{C}} \mathrm{Al}$ that show no statistically 762 significant uptake difference between states during the time scale of the experiment. C, Mass 763 spectra and deuterium uptake plot of peptide 1017-1035 that displays a bimodal isotopic pattern 764 (EX1) in the presence of TA12. The EX1 behavior is characterized by an increase in the peak width due to the overlap of two distinct isotopic distributions corresponding to the low (red) and high (green) $\mathrm{m} / \mathrm{z}$ populations. The center of these two distributions (blue, mix $\mathrm{m} / \mathrm{z}$ ) was used to generate the fractional uptake difference values for peptide 1017-1035 (panel A).

Figure 2 | TA12 blocks BonT/A1 binding to SV2C-LD by targeting a common area on HcA1. A, Effects of SV2C-LD binding on the deuterium uptake behavior of $\mathrm{H}_{C} A 1$. The Fractional uptake difference plot was generated for each peptide and at each time point by subtracting the uptake values measured in the SV2C-LD unbound-state from those in the bound state. Positive numbers indicate SV2C-LD induced protection (regions 1, 2, and 3). Regions displaying statistically significant changes of deuterium uptake upon SV2C-LD binding (Wald test, $p<0.05)$ are highlighted in gray. Each dot corresponds to an average of three independent replicates. B, Mapping of the HDX-MS results obtained after 60 min labeling onto the surface representation of $\mathrm{H}_{\mathrm{C}} \mathrm{A} 1$ (pdb \# 2NZ9). As observed with TA12, the largest reduction in deuterium uptake occurs within region 2 (i.e., 1145-1154 corresponding to region 5 in Figure 1A, 1B). The position of the SV2C-LD binding site identified by X-ray crystallography is also reported (magenta). The $\mathrm{H}_{\mathrm{C}} \mathrm{A} 1$ residues in direct interaction with SV2C-LD are indicated. "No change" refers to regions of BoNT/A1 that show no statistically significant uptake difference 
782 between states during the time scale of the experiment. $\mathbf{C}$, Inhibition of $\mathrm{H}_{\mathrm{C}} \mathrm{A} 1$ binding to SV2C783 LD by mAb TA12. $\mathrm{H}_{\mathrm{C}} \mathrm{A} 1(200 \mathrm{pmol})$ was preincubated with or without TA12 for $15 \mathrm{~min}$ at

784

785

786

787

788

789

790

791

792

793

794

795

796

797

798

799

800

801

802

803

804

805

806

807

808

809

810

811

812

813

814

815 room temperature (Input) and then incubated with immobilized SV2C-LD on glutathioneSepharose $4 \mathrm{~B}$ beads for $90 \mathrm{~min}$ at $4^{\circ} \mathrm{C}$. Bound $\mathrm{H}_{\mathrm{C}} \mathrm{A} 1$ was detected by $10 \%$ SDS-PAGE analysis after Coomassie blue staining. Load input volumes on gel were 1:10 of the total input volumes. TA12 was dissociated in heavy and light chains. A representative figure of 4 is shown.

Figure 3 | Effects of TA12 on the binding of the GT1b ganglioside. A, Structure of the $\mathrm{H}_{\mathrm{C}} \mathrm{A1}$ :GT1b complexe (pdb \# 2VU9) showing the position of the GT1b-binding site relative to the HDX-MS defined TA12 epitope. GT1b is shown as green sticks. A close-up view of the GT1b-binding interface is shown on the right side, where the position of residues Y1117 and F1252 involved in the coordination of GT1b are reported. The GT1b sialic acid 5 (Sia5) and galactose 4 (Gal4) hydrogen bonded respectively to Y1117 and F1252 are also indicated. The variations in deuterium uptake imposed by TA12 binding on $\mathrm{H}_{\mathrm{C}} \mathrm{A} 1$ are colored as in Figure 1. B, TA12 inhibition of $\mathrm{H}_{\mathrm{C}} \mathrm{A} 1$ binding to GT1b. $\mathrm{H}_{\mathrm{C}} \mathrm{A} 1(10 \mathrm{nM})$ was preicubated with or without increasing concentration of TA12 for $15 \mathrm{~min}$ at room temperature and then exposed to GT1b coated on 96-well plate $\left(1 \mu \mathrm{g} /\right.$ well). Bound $\mathrm{H}_{\mathrm{C}} \mathrm{A} 1$ to GT1b was detected with rabbit anti- $\mathrm{H}_{\mathrm{C}} \mathrm{A} 1$ antibodies and HRP-goat anti-rabbit IgG. Representative experiment in triplicate is shown. TA12 $128 \mathrm{nM}$ and above completely prevent the binding of $\mathrm{H}_{\mathrm{C}} \mathrm{A} 1(10 \mathrm{nM})$ to GT1b.

Figure 4 TA12 binds HCA1 on the face opposite occupied by both ciA-C2 and the BoNT/A1-neutralizing therapeutic human monoclonal antibody CR1. Superposition of the structures of the $\mathrm{H}_{\mathrm{C}} \mathrm{A} 1$ :ciA-C2 (pdb \# 5L21), $\mathrm{H}_{\mathrm{C}} \mathrm{A1}$ :CR1 (pdb \# 2NYY), $\mathrm{H}_{\mathrm{C}} \mathrm{A} 1$ :GT1b (pdb \# 2VU9) and $\mathrm{H}_{\mathrm{C}} \mathrm{A1}$ :gSV2C (pdb \# 5JLV) complexes. GT1b and the N559-glycan of gSV2C are shown as green and cyan sticks respectively. CiA-C2 (dark red) partially occupies the binding site on $\mathrm{H}_{\mathrm{C}} \mathrm{A} 1$ of both the N-glycan (N559) and the peptide moieties of gSV2C, thereby interfering directly with gSV2C (cyan) binding to $\mathrm{H}_{\mathrm{C}} \mathrm{A} 1$. The region of $\mathrm{H}_{\mathrm{C}} \mathrm{A} 1$ containing critical residues for gSV2C binding (i.e., T1145 and T1146) and targeted by ciA-C2 is indicated by a black box. The BoNT/A1-neutralizing CR1 antibody (ribbon representation, gold) directly targets the gSV2C N599-glycan binding site on $\mathrm{H}_{\mathrm{C}} \mathrm{A} 1$ without competing with the gSV2C peptide binding site (black box). The variable region in the CR1 light chain overalps almost completely with the ciA-C2 binding areas containing the gSV2C N599-glycan interaction site. The HDX-defined TA12 epitope (see color code in Figure 1) occupies the gSV2C peptide binding site targeted by ciA-C2 (black box), causing direct interferences with the peptide 
816 moieties of gSV2C. In contrast to both ciA-C2 and CR1, TA12 does not affect the gSV2C 817 glycan binding region but recognize a region of the GT1b-binding site. Thus, TA12 partially 818 impaired $\mathrm{H}_{\mathrm{c}} \mathrm{A}$ 1binding to GT1b (Fig. 3B). The position of the TA12 epitope relative to the ciA$819 \mathrm{C} 2, \mathrm{CR} 1$ and gSV2C binding sites is better visualized using the $\mathrm{H}_{\mathrm{C}} \mathrm{A} 1$ surface representation 820 shown on the right side. TA12 shares a common binding interface with cia-C2 but mainly 821 occupies the face opposite on $\mathrm{H}_{\mathrm{C}} \mathrm{A} 1$ to both ciA-C2 and CR1 (black circle). The position of the 822 N1006 residue identified as important for TA12 binding is indicated.

823

824

825 
Table 1. Neutralization activity of TA12 mAb with BoNT/A subtypes

\begin{tabular}{ccccccccc}
\hline $\begin{array}{c}\text { TA12 mAb } \\
\text { quantity } \\
\text { (ng/mouse) }\end{array}$ & $\mathbf{0}$ & $\mathbf{1 0 , 0 0 0}$ & $\mathbf{2 , 5 0 0}$ & $\mathbf{1 , 0 0 0}$ & $\mathbf{2 5 0}$ & $\mathbf{2 5}$ & $\mathbf{2 . 5}$ & $\begin{array}{c}\text { mAb quantity } \\
\text { (ng/mouse) } \\
\text { yielding 50\% } \\
\text { neutralization }\end{array}$ \\
\hline BoNT/A1 & $6 / 6$ & $0 / 2$ & $/$ & $0 / 4$ & $1 / 7$ & $4 / 10$ & $6 / 6$ & $2.5<25$ \\
BoNT/A2 $^{*}$ & $9 / 9$ & $/$ & $0 / 9$ & $/$ & $6 / 9$ & $9 / 9$ & $/$ & 250 \\
BoNT/A3 $^{*}$ & $9 / 9$ & $/$ & $0 / 9$ & $/$ & $0 / 9$ & $6 / 9$ & $/$ & $25<250$ \\
BoNT/A5 & $6 / 6$ & $5 / 8$ & $4 / 4$ & $8 / 8$ & $5 / 5$ & $2 / 2$ & $/$ & $1,000<10,000$ \\
BoNT/A7 & $6 / 6$ & $1 / 6$ & $5 / 6$ & $5 / 8$ & $8 / 8$ & $2 / 2$ & $/$ & $250<1,000$ \\
\hline
\end{tabular}

829

830

$831 \mathrm{mAb}$ neutralization activity was determined using the mouse protection assay with estimated

$8325 \mathrm{MLD}_{50} / \mathrm{mL}$ of BoNT/A subtype and serial dilutions of $\mathrm{mAb} .5$ estimated $\mathrm{MLD}_{50} / \mathrm{mouse}$

833 were incubated with 2.5 to $10,000 \mathrm{ng}$ of TA12 $\mathrm{mAb}$ for $30 \mathrm{~min}$ at room temperature and the

834 mixture $(0.5 \mathrm{~mL})$ was injected intraperitoneally into each mouse.

835 Results are expressed as the number of dead mice versus the total number of mice.

836 *Data from (23). 
Table 2. Binding affinities of mAb TA12 with BoNT/A subtypes $\mathrm{H}_{\mathrm{C}}$

839

\begin{tabular}{|c|c|c|c|c|}
\hline BoNT/A HC & $\begin{array}{c}\text { Amino acid } \\
\text { identity }^{\mathrm{a}}(\%)\end{array}$ & Kon $\left(1 / M_{s}\right)$ & Koff $(1 / s)$ & $\mathbf{K}_{\mathbf{D}}(\mathbf{p M})$ \\
\hline $\mathrm{H}_{\mathrm{C}} \mathrm{A} 1$ & - & $3.0110^{5}$ & $7.110^{-6}$ & 23.6 \\
\hline $\mathrm{H}_{\mathrm{C}} \mathrm{A} 2$ & 87.0 & $6.9610^{5}$ & $7.7410^{-5}$ & 111 \\
\hline $\mathrm{H}_{\mathrm{C}} \mathrm{A} 3$ & 86.58 & $1.1310^{6}$ & $6.5810^{-5}$ & 58.1 \\
\hline $\mathrm{H}_{\mathrm{C}} \mathrm{A} 4$ & 91.76 & $2.1310^{5}$ & $5.9110^{-4}$ & 2780 \\
\hline $\mathrm{H}_{\mathrm{C}} \mathrm{A} 5$ & 94.11 & $7.9510^{5}$ & $7.5510^{-4}$ & 949 \\
\hline $\mathrm{H}_{\mathrm{C}} \mathrm{A} 7$ & 91.76 & $2.8310^{5}$ & $5.9410^{-4}$ & 2100 \\
\hline $\mathrm{H}_{\mathrm{C}} \mathrm{A} 1 \mathrm{R} 1156 \mathrm{M}$ & & $4.7910^{5}$ & $1.4710^{-5}$ & 30.7 \\
\hline $\mathrm{H}_{\mathrm{C}} \mathrm{A} 1 \mathrm{~V} 1143 \mathrm{I} / \mathrm{M} 1144 \mathrm{~V}$ & & $6.4210^{5}$ & $5.6310^{-6}$ & 8.77 \\
\hline $\mathrm{H}_{\mathrm{C}} \mathrm{A} 1 \mathrm{~V} 1143 \mathrm{I} / \mathrm{M} 1144 \mathrm{~V} / \mathrm{R} 1156 \mathrm{M}$ & & $4.0910^{5}$ & $4.6110^{-5}$ & 113 \\
\hline $\mathrm{H}_{\mathrm{C}} \mathrm{A} 1 \mathrm{~N} 1006 \mathrm{~A}$ & & $1.8810^{5}$ & $1.2710^{-3}$ & 6755 \\
\hline
\end{tabular}

840

$841{ }^{a}$ Amino acid identity between $\mathrm{H}_{\mathrm{C}} \mathrm{A} 1$ and the other $\mathrm{H}_{\mathrm{C}} \mathrm{A}$ subtypes

842

843

844 
Figure 1

846

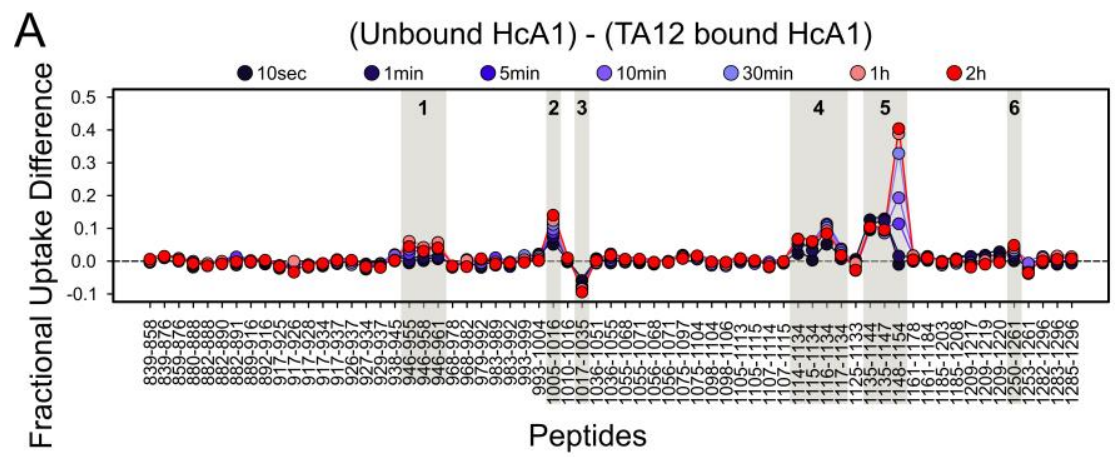

B
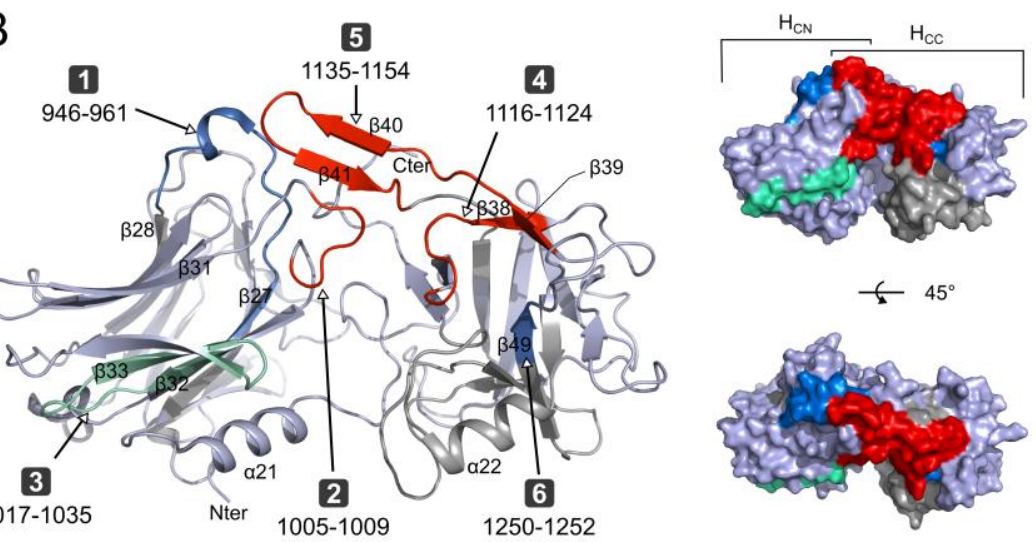

C Peptide 1017-1035
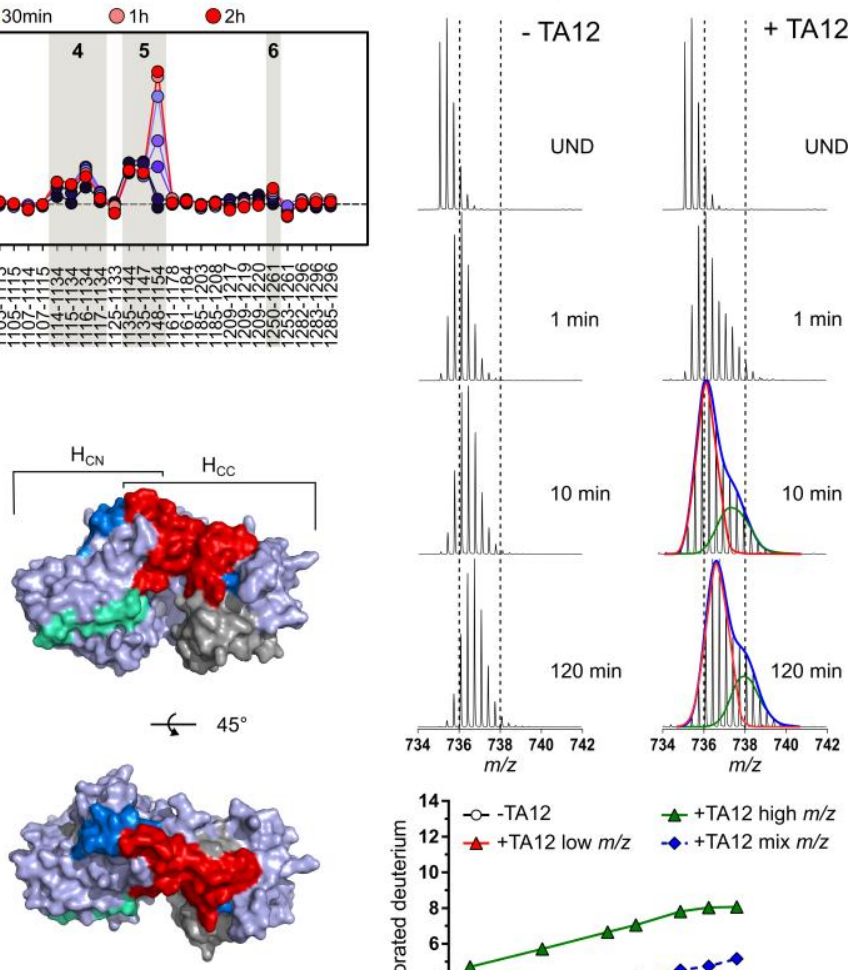

Major reduction ( $\geq 1.0 \mathrm{Da}) \quad \square$ Change in dynamics

$\square$ Minor reduction $(\geq 0.5 \mathrm{Da})$

$\square$ No change

No data

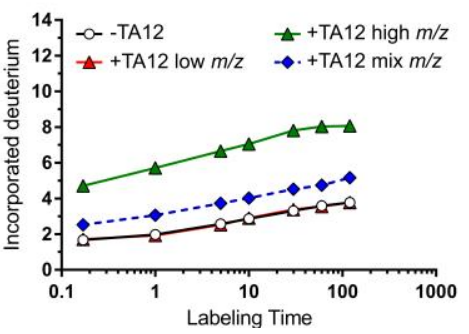


Figure 2

850
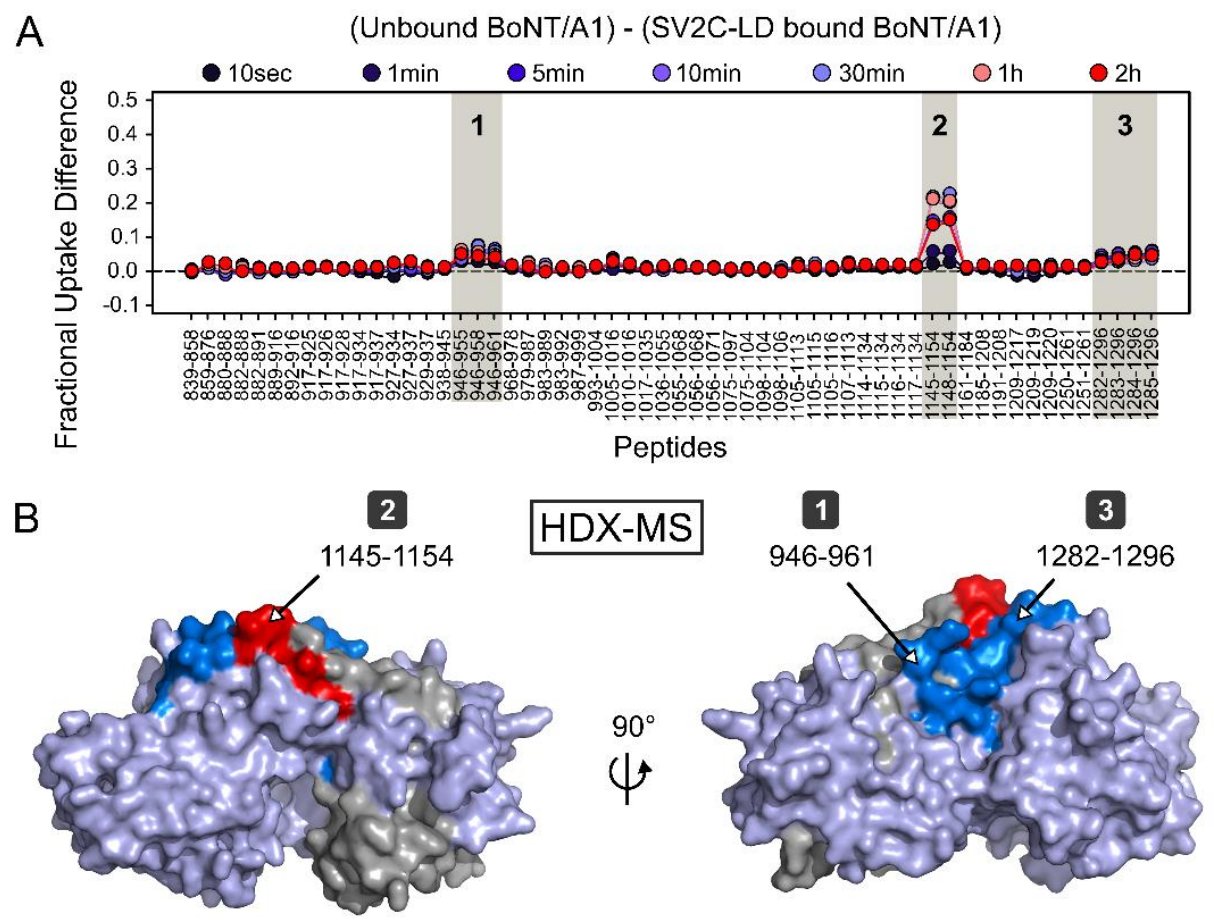

$\square$ Major reduction ( $(21.0 \mathrm{Da}) \quad \square$ Minor reduction ( $\geq 0.5 \mathrm{Da}) \quad \square$ No change $\square$ No data
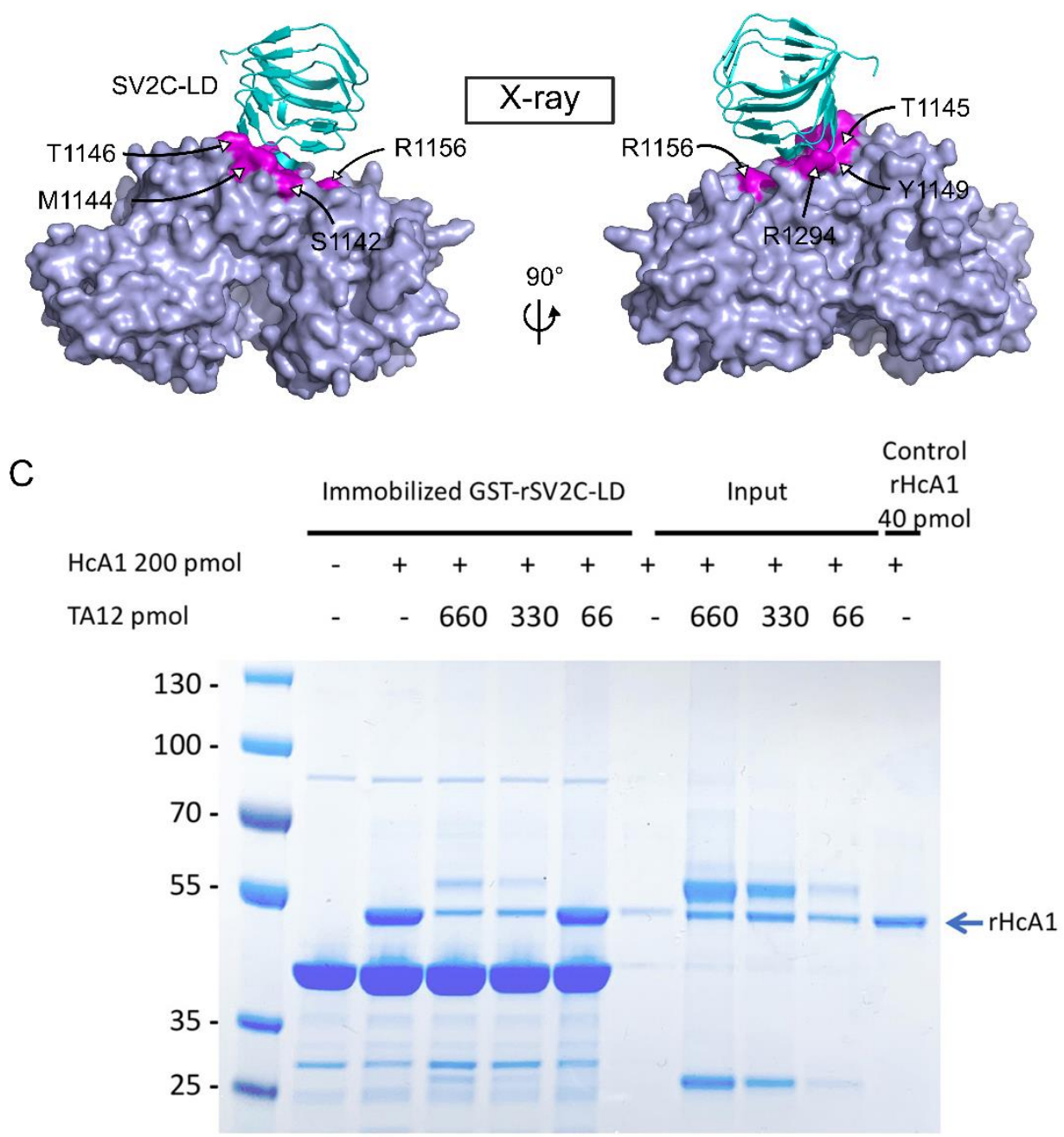
$852 \quad$ Figure 3

853

A

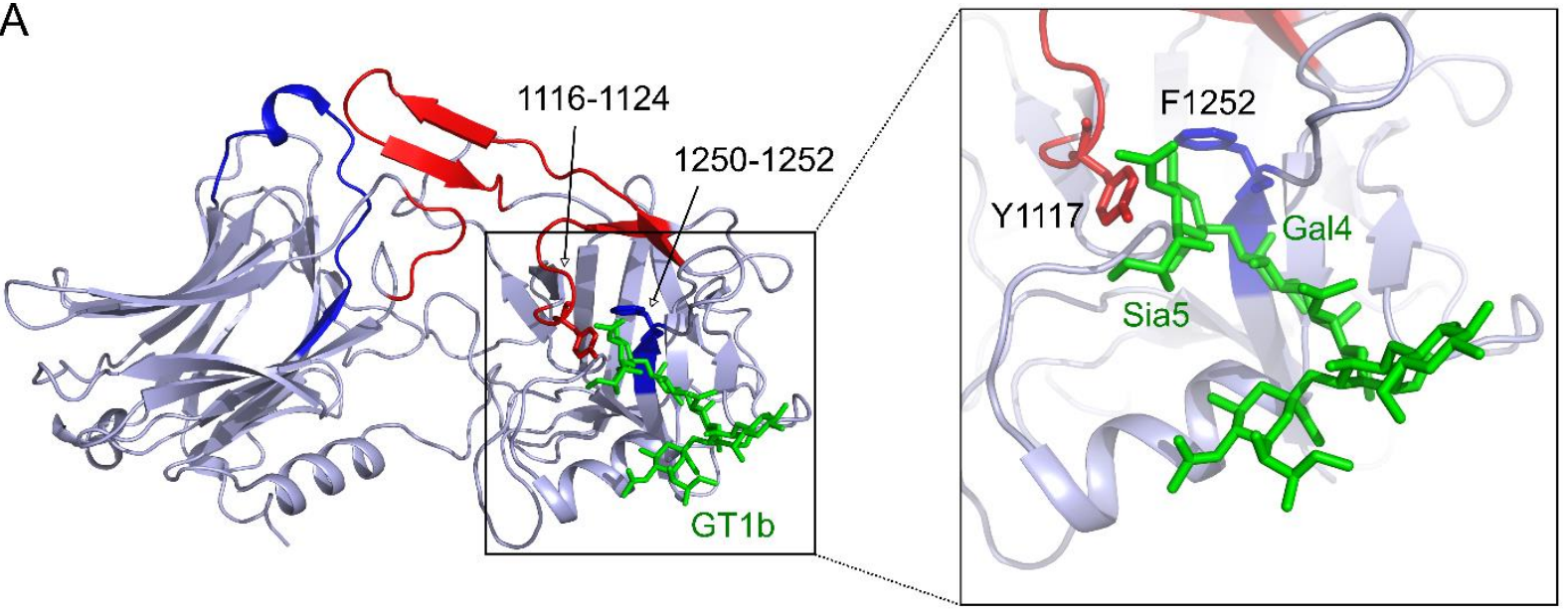

B

GT1b binding Inhibition

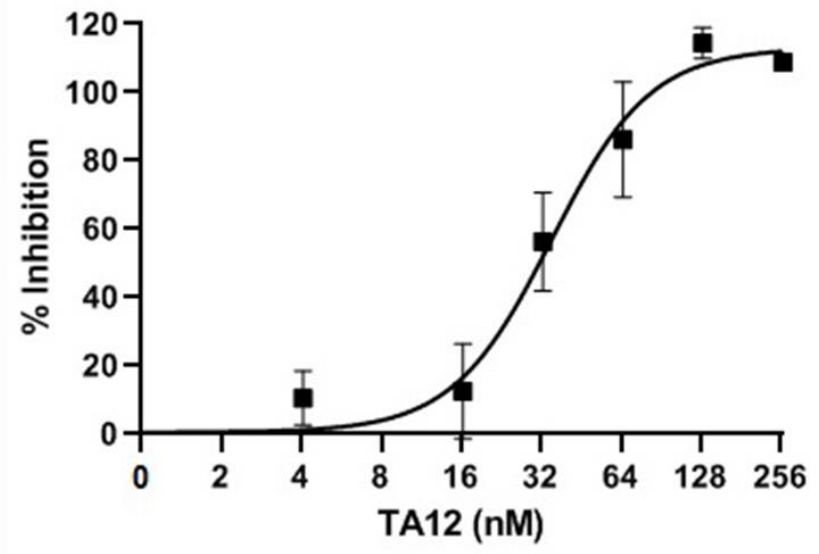

854 
855

856

857
Figure 4

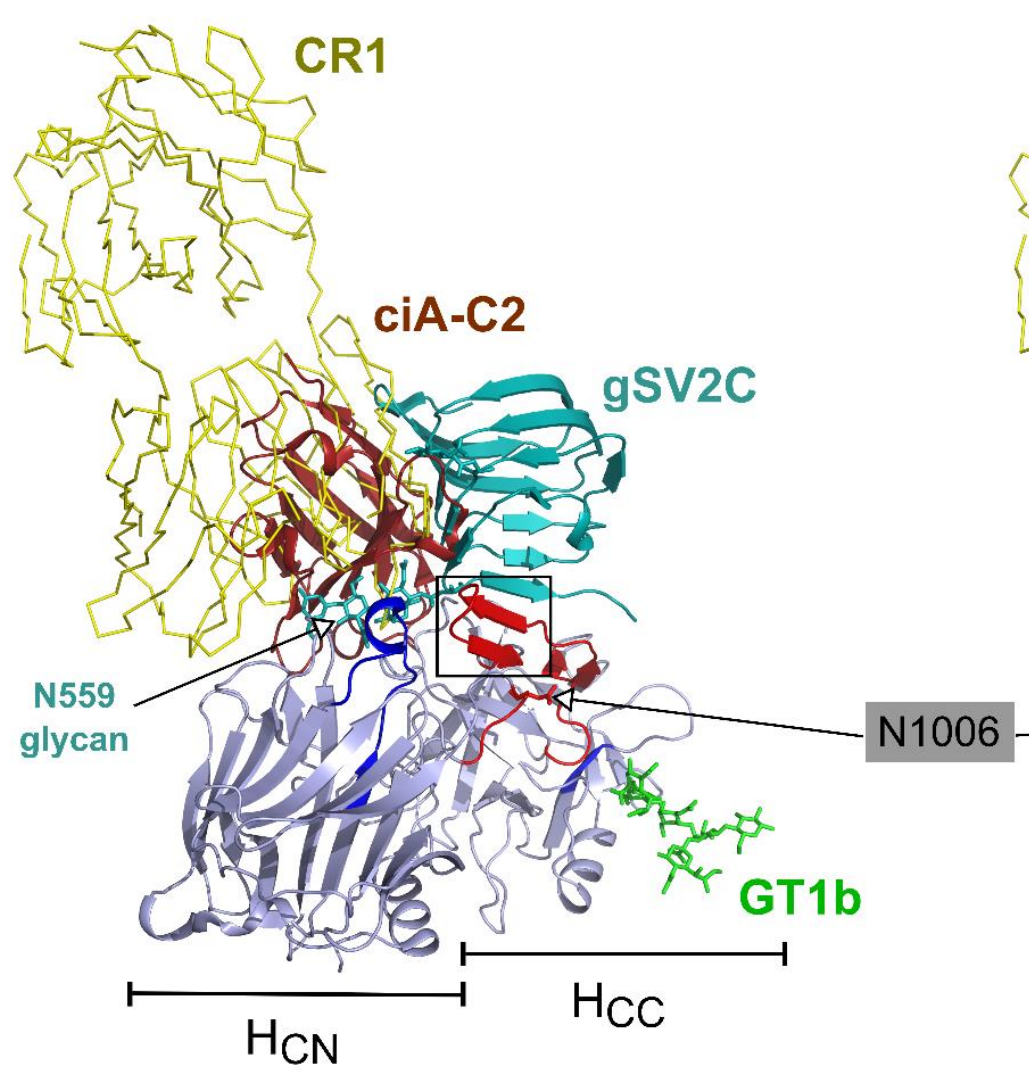

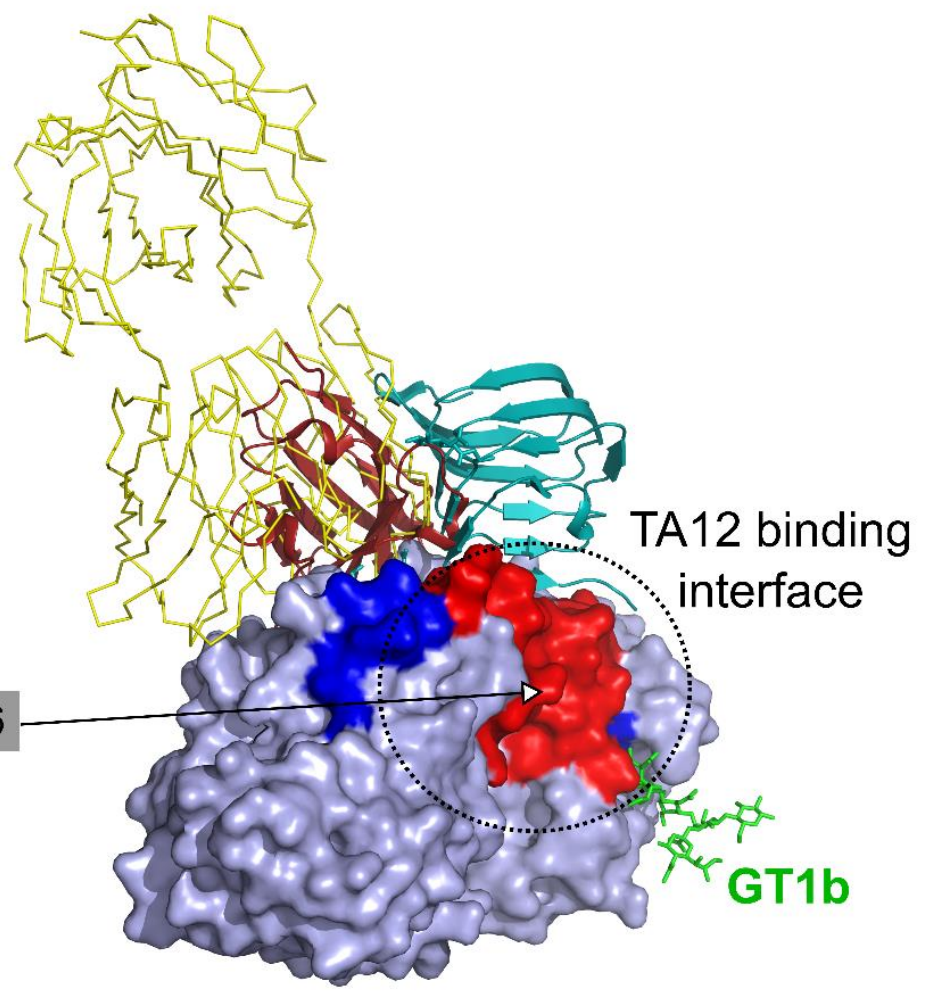

